\title{
VESTIMENTA MORISCA VALENCIANA
}

\author{
Carmen Barceló y Ana Labarta*
}

Tres grups religiosos (musulmans, cristians i jueus) composaven la societat valenciana del període medieval. La vestimenta de cada grup era diferent de la dels altres en alguns aspectes perquè a l'època importava molt distingir les persones segons llurs creences; cada grup mantenia la seua roba tradicional i a més a més el grup dominant prohibia als altres portar la pròpia dels cristians tot obligant els homes de les altres religions a dur distintius peculiars. Gràcies als treballs i estudis duts a terme per BERNIS (1956, 1959, 1962, 1978 y 1979) coneixem les modes i els aspectes de la indumentària de la societat cristiana espanyola dels segles XV i XVI.

Ací ens interessen els musulmans, la situació dels quals canvià radicalment a partir del baptisme forçós del 1526 ja que, pel que fa a la vestimenta, el rei d'Espanya els manà deixar llur roba d'època medieval i vestir a la cristiana donat que ja pertenyien a aquest grup. Encara que la comunitat musulmana batejada va aconseguir una moratòria d'uns anys, a partir de mitjan segle s'havia produit un canvi significatiu i l'abandó de la roba 'morisca', sobre tot entre els homes; tanmateix l'adjectiu morisc es va fer servir als escrits cristians, d'una manera ampla que ultrapassa els límits tradicionals de l'Edat Moderna, per referir-se a coses que tenien relació amb el món dels musulmans i més tard, dels nou conversos.

Fins a hores d'ara s'ha dedicat molt poca atenció a estudiar quin aspecte tenia la població morisca valenciana pel que fa als vestits, complements i joies. L'estudi dels vestits i altres ornaments d'aquest grup de la societat valenciana medieval i moderna pot ajudar a resoldre la mancança d'imatges sobre els homes, dones i xiquets d'un passat tant allunyat de nosaltres.

Quan es tracta d'il·lustrar l'època morisca les imatges més repetides i difoses són les dels moriscos granadins dibuixats pel viatger alemany Christoph WEIDITZ (1529) i les representacions de Felipe Bigarny, en baix relleu, al retaule major de la Capilla Real de Granada. Igualment difosos són els textos dels viatgers estrangers a la Península, en anys poc anteriors o posteriors a la conquesta de Granada com MüNZER (1494-1495) i NAVAGERO (1525-1526), que for-

\footnotetext{
* Universitat de València.
} 
neixen minucioses descripcions de la vestimenta dels pobladors de l'antiga capital musulmana.

Això ha fet que es tinga en general una idea global i uniforme de l'aspecte extern dels moriscos com si, al llarg de tot el període que va des del 1492 a l'expulsió del 1609 a tots els indrets de la Península, aquest grup social haguès portat la mateixa roba que portaven els granadins a principis del segle XVI.

El text que segueix és una reelaboració i actualització del treball que vàrem publicar ja fa bastants anys sobre aquest tema (BARCELÓ \& LABARTA, 1985). Vàrem basar aquell estudi en la documentació àrab que coneixiem, tot acompanyant-la d'altres notícies trobades a inventaris i documentació valenciana i inquisitorial. Ara hem afegit a aquella primera aproximació més dades procedents de nous documents àrabs apareguts els darrers anys i algunes altres representacions gràfiques. Malgrat tot, pensem que la indumentària morisca valenciana mereixeria treballs molt més amplis, aprofitant l'abundor d'inventaris a la documentació cristiana.

Hem volgut deixar de banda els temps immediats a la conquesta del segle XIII i de bona part del segle XIV perquè gairebé no tenim documentació àrab amb informació suficient per a fer-nos una idea clara de com vestien i tampoc no s'han publicat prous inventaris de roba de la població musulmana. Trobem, però, una mostra del vestuari d'aquest període en un document de l'any 1372 que ens forneix l'imatge d'una familia d'emigrants d'Eslida que se n'anaren a Berberia:

"Vestie lo dit Mahomet Abenjuceff [el pare], dues gonelles de drap de la terra blaves squinçades, e un manto de burell negre squinçat, e capell e correja...

Vestie la dita Façem, muller del dit Mahomat, una aljuba de drap blau de la terra oldana e una almexia de drap de cotonina e un sobrecap...

Vestie la dita Axa, filla lur, una aljuba de drap de lenç e un sobrecap e unes orelleres de argent...

Vestie lo dit Hamet, fill lur, II camises de lli oldanes, una correja, una gonella blava e una capa de burell negre e una altra gonella blava squinçada...

Vestie lo dit Abdal·la [l'altre fill] II caçots, la un de lli blanch e l'altre de lenç blau e una gonella de drap burell e una capa blava oldana e una correja" (FERRER I MALLOL, 1987: 317, doc. 102).

Malgrat el detallat inventari no sabem, però, si aquesta roba descrita era la més roín que tenien i l'usaven per al viatge o portaven la que era diària i tenien per costum. A més duien a l'equipatge "set almeixies i una aljuba de dona, a més d'onze alquinals, dos alhirems (o alfirems) i una alhamia de dona" (FERRER I MALLOL, 1987: 42).

És ben sabut que alguns vestits musulmans foren adoptats pels cristians des de molt prompte (com trobem sovint a les cròniques de Jaume I o de Muntaner, entre d'altres, que en testimonien el seu ús) i els noms d'aquestes robes passaren a designar objectes determinats en llur món casolà, mantenint-se'n els noms durant segles sense perdre's, com ho prova el fet que al segle XV Jaume Roig els utilitze al seu Spill; per exemple, en descriure la indumentària d'una beguina: 
"Que desús vist I cot e mantell | de gros burell, | roba jussana | de fina llana, I prima, llistada, I verd, blau pintada I ; duia almexia | [...]".

$\mathrm{O}$ que hom trobe, a un inventari de les robes del rei Alfons $\mathrm{V}$, noms de vestits adjectivats 'morisc' (vegeu ací, s.v. aljuba). En alguna ocasió trobem a la literatura valenciana del Segle d'Or alguna descripció curiosa, no pel que fa a la roba cristiana sinó a la morisca, com hom pot llegir al Tirant lo Blanc de Joanot Martorell quan Plaerdemavida, a Tunis estant, "s' abillà aquell dia com a mora molt honradamment e alcofollà's molt bé los ulls perquè no fos coneguda"; descrivint-nos després la seua indumentària: "la donzella, esquinçà's l'aljuba e la camisa que vestia fins baix als pits, mostrant les mamelles, e pres lo cos de Tirant e posà'l sobre les sues faldes". I més tard, quan l'heroi vol desagreujar-la i fer-li els honors de reina, la seua amada fou "vestida d'un manto de brocat carmesí forrat d'erminis, que Tirant li féu traure dels seus per ço com tota l'aljuba s'havia esquinçada [...] Tirant li havia llevat l'alquinal e era restada en cabells".

Sabem que, al menys des de el segle XIV, els mudèjars valencians havien de vestir un signe distintiu ("una tovallola blava en lo cap"), no podien portar armes i duïen tallats els cabells d'una forma específica (FERRER I MALLOL, 1987: 43 i ss.), tot i que els senyors els permetien incomplir aquestes normes (BARCELÓ, 1984: 85). El 1486 el rei Ferran, arran la presència d'alguns bandolers, explica que això ocórre "per no anar senyalats los dits moros, ans vestits indifferentment com a crestians [...] e sens barbes ni toques ni altres senyals de moros" (MEYERSON, 1986: 106, n. 15).

Les normes sobre el vestit mudèjar havien de canviar a partir de l'ordre de conversió general dels musulmans valencians que es publicà el 1526. A més del baptisme, deixarien de portar armes i llur indumentària morisca. En juliol del 1528, però, el rei acceptava les respostes de l'Inquisidor General, Juan Garcia, sobre els continguts del decret de conversió que havia pactat amb els dotze síndics representants de les aljames i moreries del regne de València, on figurava el capítol següent:

"Item por quanto los dichos moros tienen bestidos moriscos los quales son differentes de los bestidos de los christianos, señaladamente en lo de las mugeres a las quales sería muy grave averlo de mudar y se perderían porque ningún provecho se podría sacar dellos, suplican por ende que por espacio de los dichos quarenta años no puedan ser forzados de mudar los dichos bestidos" (BORONAT, 1901: I, 423).

Gràcies al pacte, els deixaren continuar vestint igual que adés durant deu anys i no quaranta com havien demanat.

Passat el temps establert, no havien canviat molt les coses i per això els informes i els manaments de "quitarles el vestido" són abundosos. Amb tot i amb això, sobre la situació dels moriscos de la diòcesi de Sogorb el bisbe escrivia al Consell del rei el 30 de juliol del 1587 diverses consideracions, entre les quals:

"Item. Por las dichas razones claramente queda provado y concluído que para la conversión y reducción de los dichos moros no es necesario ni de efecto alguno quitarles el hávito y lengua que usan ni sacarlos de los lugares marítimos 
en que viven, pues, como stá dicho y es evidente y notorio, falta esto en los moros de Aragón y Castilla, que son muy ladinos en lengua castellana y usan vestido de christianos viejos y viven en lugares muy lejos de los mares, y con todo esto son tan moros como los de Berbería y los del Reyno de Valencia" (BoroNAT, 1901: I, 629).

L'adaptació a la nova indumentària va anar endavant a poc a poc, com es mostra en el vocabulari que recollim al present treball el qual ha estat documentat en aquest període; els noms dels vestits que usaven en són prova i l'adopció del nom castellà o valencià a l'àrab tant sols significa quin fou el camí d'entrada dels manlleus.

Les deliberacions dels consells del rei i dels bisbes sobre la situació dels moriscos pel que fa a llur vestimenta encara continuaven durant els anys immediatament anteriors a l'expulsió. Així, es va tractar a una de les Juntes de València de gener del 1600:

“También se leyó una carta del obispo de Orihuela en que [diu] sabía que [...] muchas mugeres de los lugares de Petrel y Elda habían dexado el vestido morisco; hasta que los principales hicieron una junta secreta en la que determinaron muchas cosas y entre ellas que sus mugeres no dexasen el bestido morisco" (BoRONAT, 1901: II, 18, n. 27).

Un testimoni interessant des del punt de vista que ací tractem és una descripció que va fer Bartolomé Joly (1603-1604), conseller i almoiner del rei de França que viatjava en companyia del senyor de Boucherat, abat i general del cistercencs francesos. Durant la seua visita a Gandia explica que "después de la comida, el señor del Císter [és a dir l'abat francés] quiso que aquellas gentes viniesen a bailar a la morisca, al son de una gran guitarra como un laúd que uno de ellos tocaba sin distinción de sonidos; después aparecieron tres o cuatro bailarines moros y seis mujeres, más modestas que bellas, vestidas con trajes de tela trabajada de seda, con grandes y anchas mangas abiertas por los costados, de seda de color, un pequeño sombrero sobre la cabeza, zapatos rayados en los pies, [...] tenían también sortijas de oro y de plata, brazaletes y collares en los dedos y en los brazos, en el cuello y en las orejas, pendientes monstruosamente grandes" (GARCÍA MERCADAL, 1959: II, 78).

Algunes de les peces de roba i de joies femenines detallades pel visitant francés a Gandia es troben descrites en inventaris i documents cristians; altres són esmentades als textos àrabs dels moriscos (cartes de noces, comptes, relacions de béns, etc). També els moriscos i morisques de la baronia de Planes i zones pròximes vestien en aquests anys robes vistoses, de colors cridaners -verd, blau, groc i roig-, amb randes, brodats i en teixits de seda (molt més present entre els moriscos que al vestuari dels cristians), freqüentment brodada (MAISO \& BLASCO, 1983: 350).

Al setembre de 1608 el tema de l'hàbit morisc encara fou motiu de consultes. El rei Felip IV escrivia una carta al marqués de Caracena, virrei de València, fent-se'n ressó: "Háse considerado que el quitar de golpe a essa gente el 
trage de moros y hablar su lengua podría ser causa de irritarlos y dificultar más su converssión, y que sería mejor que se procurasse que se fuessen aficionando a la fee y al trage de los christianos viejos, y que los recivan como hermanos a la reconçiliación dando a los reconciliados algún premio como sería vestirlos de nuebo por ynsignia de honrra" (BORONAT, 1901: II, 140).

I va estar present en els temes tractats per la Junta de València del 22 de novembre del 1608: “Tratóse si convernía hazer fuerça en quitarles la lengua y algunos vestidos que han quedado. Pareció que lo primero tenía grande difficultad, o imposibilidad para lo presente; y que en lo segundo se procediese con moderación, atenta la poca importancia que traya consigo y estar casi remediado en los obispados de Tortosa y Segorbe y en el Arçobispado de Valencia, quedando sólo en el obispado de Orihuela algo, aunque poco" (BORONAT, 1901: II, 135).

La col·lecció pictòrica que es féu per encàrrec reial per tal de commemorar l'embarcament i expulsió dels moriscos i també les revoltes a la serra de Laguar i la Muela de Cortes ofereix una panoràmica visual de dones, homes i xiquets moriscos (Expolsión, 1997). No està clar fins a quin punt els pintors eren fidels a la realitat o n'han fet una representació estereotipada. No sabem si hi havia diferències en els vestits entre zones molt allunyades (Castelló-Alacant) ni entre el camp i la ciutat o entre rics, pobres i no tan pobres. En tot cas, el que podem assenyalar és que a banda de la indumentària de les morisques més tòpiques -com les adés esmentades de Gandia- veiem a les pintures homes rics, i també llurs dones i xiquetes morisques, vestits igual que els cristians i cristianes vells.

Per la nostra part, hem recollit les dades que hem trobat sobre indumentària a partir de la lectura dels processos inquisitorials contra moriscos, d'inventaris de béns requisats i altres notícies soltes procedents de la documentació cristiana. De la mateixa manera hem procedit amb els documents àrabs (uns ja editats i estudiats per nosaltres o per altri, d'altres recentment publicats), els hem despullat i n'hem traduït les citacions. Hem ordenat alfabèticament el material que hem extret en les tres llistes que oferim seguidament: una de robes, altra de joies i una tercera de teixits i altres complements. A més, hem afegit a cada veu d'entrada comentaris o notícies que ens han paregut aclaridores o interessants sense, però, pretendre esgotar el tema.

Volem assenyalar, d'altra banda, que el nostre treball només té el propòsit de recollir i identificar els termes documentats, sense analitzar-ne més profundament el valor testimonial de cada font. Estudis ulteriors, destinats a analitzar l'evolució de la indumentària morisca, hauran naturalment de tenir en compte si un cap de vestir determinat és esmentat en un inventari de béns o una carta de noces (puix que podria tractar-se, en aquest cas, de roba ja en desús, transmesa de pares a fills o millor de mare a filla) o si, per contra, consta a la documentació que en tal data el vestia algú. També s'haurà de tenir en compte que n'hi havia de diari i de festa; i que no vestien igual els rics i els pobres, els adults i els xiquets... 
Finalment, volem ressaltar que no hem fet cap comparació amb la vestimenta morisca d'altres regions (hi ha nombrosos treballs i abundant material, en particular sobre la de Granada) ni amb la indumentària dels andalusins o els àrabs en general (vegeu DOZY, 1845; MARÍN, 1997, 1998 y 2001; SERRANO-NIZA, 2005). Pensem que fins que no coneguem millor el món morisc valencià és difícil establir convergències, similituds o diferències. Entre tant, barrejar els materials només pot portar-nos a confusió.

\section{ROBA I COMPLEMENTS EN LA DOCUMENTACIÓ ROMÀNICA I ÀRAB}

Hem respectat la grafia original de cada paraula, reproduïnt-la tal i com es troba al document; notareu que tenim termes en les tres llengües emprades aleshores a València (entre "-" la romànica; entre “_" les traduccions de 1'àrab; entre $<->$ les transcripcions de l'àrab). Ordenem el material alfabèticament i en la transcripció de l'àrab seguim les recomanacions de l'IEC i hi incloem el signe _ per tal de separar mots units a l'original.

Alcandora $<$ qandura $>$. Peça interior, d'home i de dona, coneguda i documentada a bastament; avui en diem camisa. Se cita "un coll de seda d'alcandora d'home" en un text del 1559 (BARCELÓ \& LABARTA, 1985: 65/67, 1. 22; BARCELÓ \& LABARTA, 2009, doc. 74) i en un altre del 1581-1583 "llenç per a una alcandora” (LABARTA, 1994: 2v; BARCELÓ \& LABARTA, 2009, doc. 132).

Alfilem. Documentat ja el 1372 "un alhirem de lli blanch prim" i "un alhirem de lenç prim curt" (FERRER I MALLOL, 1987: 316); el 1412-1424 es diu a l'inventari del rei Alfons V: “.j. alfilem morisch de jugar a les canyez de drap de lin blanch, ab les vores blaues e serrells a cascun cap" (ALCOVER \& Moll, s.v.); el 1426 s'ordena en Manises "que les dones no porten alfilems o alquinals o àbits de mores, ne porten la cara cuberta" (ADV, Llibre de colacions (1426), f. 331r-v). Ha de tractar-se del vel que altres fonts anomenen alfirem o alfilem i que és conegut als textos castellans com a alhareme (BERNIS, 1979: II, s.v. alharemes; vg. més avall s.v. almaizar). Pareix que ja era fora d'ús al segle XVI.

Alhamia <al-hamiyah $>$. No sabem amb certesa a quin tipus de peça de vestir es refereix aquest nom àrab. Un text del 1591 assenyala que era de seda (LABARTA, 1983: 83; BARCELÓ \& LABARTA, 2009, doc. 151). El 1372 se citava a l'inventari d'uns mudèjars d'Eslida "una alhamia de dona listada de listes vermelles de seda" (FERRER I MALLOL, 1987: 316). El 1529 es llega a una dona mudèjar "una alhamia de seda" (GARCIA-OLIVER, 2003: 129). També a Granada es documenta "una bestidura morisca, de seda y de lienço de colores que se dize ahamia" (MARTínEZ RuIz, 1972: 46-47). Pensem que pot tenir relació amb la forma "alfamia" referida a un tipus de tela que apareix dues vegades al Fuero de Alcaraz (MARTíneZ MELÉNDEZ, 1989: 469 [any 1296]). 


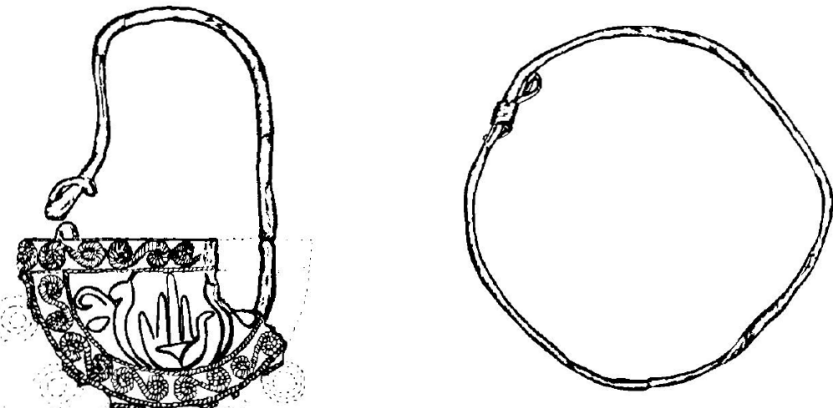

$\stackrel{0}{c m}$

$\mathrm{CAB}, 85$

Fig. 1. Arracades (Museu Arqueològic de la Plana Baixa, Borriana).

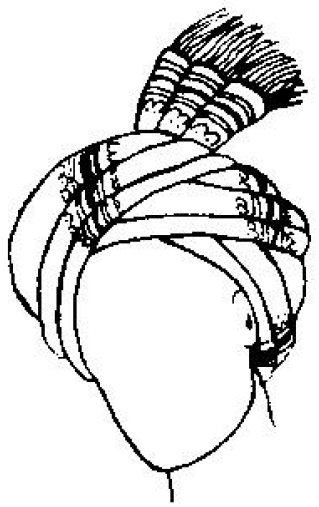

$5 \mathrm{~A}, 06$

Fig. 2. Tovallola de cap, d'home mudèjar (Jaume Huguet, m. 1492, Retaule de Sant Vicenç, Museu d'Art de Catalunya, Barcelona). 
Aljuba. El 1351 se cita un "aljuba de cotó" entre els béns d'un mudèjar d'Alfarb (BARCELÓ, 1984: 105; cfr. BERNIS, 1979: II, s.v.) i el 1372 a Eslida unes mores duien "una aljuba de drap blau de la terra oldana" $i$ "una aljuba de drap de lenç", a més de incloure a l'equipatge "una aljuba de dona de cotó morada" (FERRER I MALLOL, 1987: 317). Es documenta el 1412-1424 a l'inventari del rei Alfons V: "una aljuba morisca de drap de seda blau scur ras, ab savastra morisch per los musclos, qui han d ampla una ma; los quals son lavorats de fil d or e de seda blancha e vermella, amb vj cordons e flochs de seda blava, ab botons $\mathrm{d}$ aur e de seda vermella. Item una aljuba altre morischa de drap de seda morisch, obrat de listes largues, ab letres morisques blanques, ab altres obratges de diverses colors, forrada de bocaram blanch. Item una aljuba morischa de drap de seda d Espanya, levorat e de obratge de diverses colors de seda groga, morada e altres" (ALCOVER \& MOLL, s.v.); també se'n troben en altres textos: "una aljuba morischa de seda blanqua", "una aljuba morischa de seda listada de diverses colors" (Alcover \& Moll, s.v. [any 1433]; vegeu ací "gipó / jubón"). El fet d'utilitzar l'adjectiu 'morisc' mou a pensar que hi havia diferències entre el mateix vestit cristià i el musulmà.

Almaisar. Toca consistent en una banda molt llarga de tela que es portava enrotllada al cap com un turbant. BERNIS (1979: II, 57) suposa que era de tela de colors -generalment de seda- diferentment de l'alhareme, que es feia amb tela de lli (blanc o groguenc). El príncep de Viana en tenia el 1461: "hun almayçar negre ab ses franges d'or e de seda posat en una caparuça de vellut morada" $i$ "hun almayçar ab sos franges d'or e seda murischa" (AlCover \& MolL, s.v.); un altre inventari d'un morisc de Xarafuel cita "un almaysar blanco" encara que no especifica de quin tipus de teixit era (AHN, Inq. llig. 554/18 [any 1602]).

Almalafa $<$ malaḩfa $>$. Peça exterior, com un llençol, amb la qual s'embolicaven les dones morisques. Documentada en un text del 1591 (LABARTA, 1983: 82; BARCELÓ \& LABARTA, 2009, doc. 151).

Almeixia $<$ mxyā $>$, pl. $<$ mxyāt $>$. Peça exterior en forma de túnica i amb mànegues. Podia ser de drap o de seda i estava adornada a les vores amb brodats de colors. Està documentada entre els musulmans des del segle XIII, tant a la crònica del rei En Jaume com altres cròniques i documents romànics (".II. almeixes de li planes", ROCA, 1952: 198-199, doc. 17 [any 1284]); "una almaxia de stopa", "per tallar, cosir e guarnir quatre almexies listades, ço és dos de tot seda e les dos de fil de seda", "una almechia de seda blancha ab letres morisches" (AlCOVER \& MOLL s.v. [anys 1351, 1443, 1461]); "una almexia de drap de lenç ab listes morades", "una almexia de seda tota blancha foradada", "una almexia de drapde lenç", "una almexia de lenç oldana", "una almexia oldana de lli ab listes morades", "una almexia de hom oldana", "una almexia de lenç tenida de blau e de adzur, quasi nova", "una almexia de drap blau de la terra ab unes mànegues del dit drap" (FERRER I MALLOL, 1987: doc. 102 [any 1372]). 
En àrab pot aparéixer $<$ mxyā $>$, pl. $<$ mxyāt $>$, com a referència genèrica "almexies" (BARCELÓ \& LABARTA, 2009, doc. 73 [any 1557]) o bé fent-ne inventari detallat, com a un text de 1559 que n'esmenta: "una almeixia de seda en grog i verd", "una almeixia de seda, amb recam morat i aranjat", "una almeixia de llenç brodada en seda rosa i aranjat", "una almeixia de llenç brodada en seda roja en les bocamànegues i el faldar", "una almeixia de llenç brodada -el faldar i les bocamànegues-en seda roja" (BARCELÓ \& LABARTA, 1985: 65/66. 1. 6, 7, 8, 9, 11; BARCELÓ \& LABARTA, 2009, doc. 74).

Alpargata < bargat $>$ / <bargatā $>$. "una sàrria de alpargates" (AHN, Inq. llig. 552/37 [any 1585]). Un text valencià del 1587 fa esment a "espardenyes d'espart <bargat min halaf>", aclariment que no consta en les altres quatre citacions que n'hi ha (LABARTA, 1982: s.v.; BARCELÓ \& LABARTA, 2009, doc. 140) i tampoc no hi és a un altre llibre de comptes on apareixen al·lusions a "espardenyes" diverses vegades (LABARTA, 1994: 63, f. 1r, 2r, 6r; BARCELÓ \& LABARTA, 2009, doc. 132 [anys 1581-1583]).

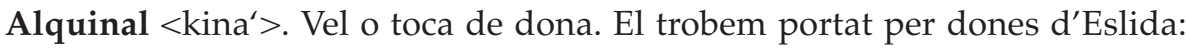
"un alquinal de lenç listat de cotó vermell ab ores morades e vermelles", "VI alquinals de diverses colors, tots de lenç" (FERRER I MALLOL, 1987: doc. 102 [any 1372]). El 1426 s'ordena en Manises "que les dones no porten alfilems o alquinals o àbits de mores, ne porten la cara cuberta" (ADV, Llibre de colacions (1426), f. 331r-v). El 1525 una morisca rep en herència de la seua germana "un alquenal o alconayia [sic per alvacaya]" (GARCIAOLIVER, 2003: 128). Un text àrab del 1591, que cita una peça d'aquest tipus, afegeix que és "morat, brodat en or" (LABARTA, 1983: 82; BARCELÓ \& LABARTA, 2009, doc. 151).

Alvacaïa $<$ wqāya $>$, pl. <waqayit $>$. Documentada a bastament ("alvacaya tota blancha de seda", AlCOVER \& Moll, s.v. [any 1348]), com ara "dos alhuaquaïes" en els béns d'un mudèjar d'Ondara (ARV, Mestre Racional 9568, f. 46v [any 1403]) i en els d'una dona de la Valldigna "dues jocaies [sic per vacaies] d'or" (GARCIA-Oliver, 2003: 129 [any 1529]). En la major part dels exemples recollits es tracta d'una peça de luxe que portaven les dones cobrint el cap, confeccionada amb seda de color i decorada de brodats d'or a les vores. És el mot aràbic <waqaya $>$, que es documenta als textos dels moriscos valencians sota les formes $<$ waqayā $>/<$ wqya $>$ / $<$ wqāya $>$, pl. $<$ waqayit $>$ / $<$ wāqayt $>$; així, en una carta de noces es donen "dues alvacaïes de bis de seda amb les vores daurades" (BARCELÓ \& LABARTA, 2009, doc. 57 [circa any 1525]) i en un text de 1559 s'esmenta "una alvacaïa rogeta amb un poquet d'or" (BARCELÓ \& LABARTA, 1985: 65/ 66, 1. 20; BARCELÓ \& LABARTA, 2009, doc. 74); en una altra carta de noces hi ha "dues alvacaïes de seda amb les vores d'or fi” (VILA, 1933; BARCELÓ \& LABARTA, 2009, doc. 80 [any 1568]); un altre document de 1570-1580 cita "dues alvacaïes de seda amb les vores d'or fi"; el 1583 apareixen "dues alvacaïes, una blanca i una roja, amb les vores brodades en fil d' or fi" i el 1591 "dues alvacaïes, una roja i una blanca, brodades en or" (LABARTA, 1983: 64, 72, 81; BARCELÓ 
\& LABARTA, 2009, docs. 99, 133, 151), a més d'“una alvacaïa" a l'inventari dels béns d'una morisca (BARCELÓ \& LABARTA, 2009: 326, doc. 154 [any 1593]) i "dues alvacaïes de seda amb les vores d'or fi" a l'eixovar d'una dona (BARCELÓ \& LABARTA, 2009: 319, doc. 148 [any 1590]).

Arrehuelo. 1585 “arrehuelo negre ab una girada de vellut” (BARCELÓ, 1984: 107).

Barret. 1513 "un camelot ab barret de bellut" (ARV, Batlia 329, f. 631).

Basquinya. Es tracta d'un vestit de dona i s'esmenta als inventaris com a roba de luxe. Segons BERNIS (1979: II, 133-134) aquest tipus de faldilla se solia guarnir amb tires d'un altre tipus de tela i d'un altre color que es cosien al voltant. Les portaven les xiquetes morisques (AHN, Inq. llig. 549/22 [any 1609]) i en la rendició de comptes d'una tutela de dues xiquetes es parla de "cosir unes vasquinyes de girasol y altres de drap vert y per fil y seda per a cosir-les" (ARV, Clero llig. 749/1949-50 [any 1583]). Les més riques, que es troben en una carta de noces, eren "de seda, guarnides de vellut", fent joc amb les mànegues, també de vellut (APN, Prot. F. Sanchis [any 1604]), o "a la cristiana, de tafetán girasol de grana y amarillo, con guarnición de terciopelo negro" (BARCELó \& LABARTA, 1985: 69 [any 1563]). Les més senzilles solien ser de drap de llana, de vegades guarnides amb tela del mateix color, com ara una morada "con faxas moradas" (AHN, Inq. llig. 554/18 [any 1602]). Els colors que s'esmenten són: blau, verd, vermell, groc i morat (AHN, Inq. llig. 554/18).

Borceguí. Aquest tipus de sabata masculina se cita el 1446 entre els béns que li van segrestar a un sabater i s'especifica que són "borceguins marroquins" (BARCELÓ, 1980: 61).

Bossa. Era un complement tant masculí com femení. Les que portaven els homes eren de llenç i podien portar a l'interior "un bolsico" (AHN, Inq. lligs. 552/37, 554/6, 1lib. 938, f.52-54 [anys 1585, 1590, 1599]). Entre les de dona, ne trobem "con una telilla" o "de telilla blanca y verde, con un cayrelico de oro" (AHN, Inq. 1lig. 555/21 [any 1602]), o de "raso colorada" (AHN, Inq. llig. 549/13 [any 1616]). La més luxosa pertanyia a una musulmana de València i es descriu el 1513 de la manera següent: "una boça de broquat migancera, de dona, ab un estoig daurat usat" (ARV, Batlia 329, f. 631).

Botons $<$ al-butunx $>$. S'esmenten, sense especificar la matèria de què eren fets, en uns comptes de 1581-1583 (LABARTA, 1994: f. 6v; BARCELÓ \& LABARTA, 2009, doc. 132), on s'ha afegit l'article àrab al mot romànic 'botons' .

Brial <ibriyāl $>$. Designava les faldilles que portaven les dones i anaven de la cintura fins als peus. Es vestia en ocasions solemnes i només era a l'abast de les morisques més riques. Se cita en textos cristians provinents de la Valldigna: en 1529 una dona llega "un brial i unes faldetes" (GARCIA-OLIVER, 2003: 129) i la esposa d'un mercader tenia un "brial vergat de cotonina, usat" (BARCELÓ, 1984: 107 [1585]). Es documenta <ibriyāl> el 1591 (LABARTA, 1983: 82; Barceló \& LabARTA, 2009, doc. 151). Segons Alc. (p. 119) equival al "pollót o saya". En diverses zones valencianes reben actualment aquest nom les sinaues. 


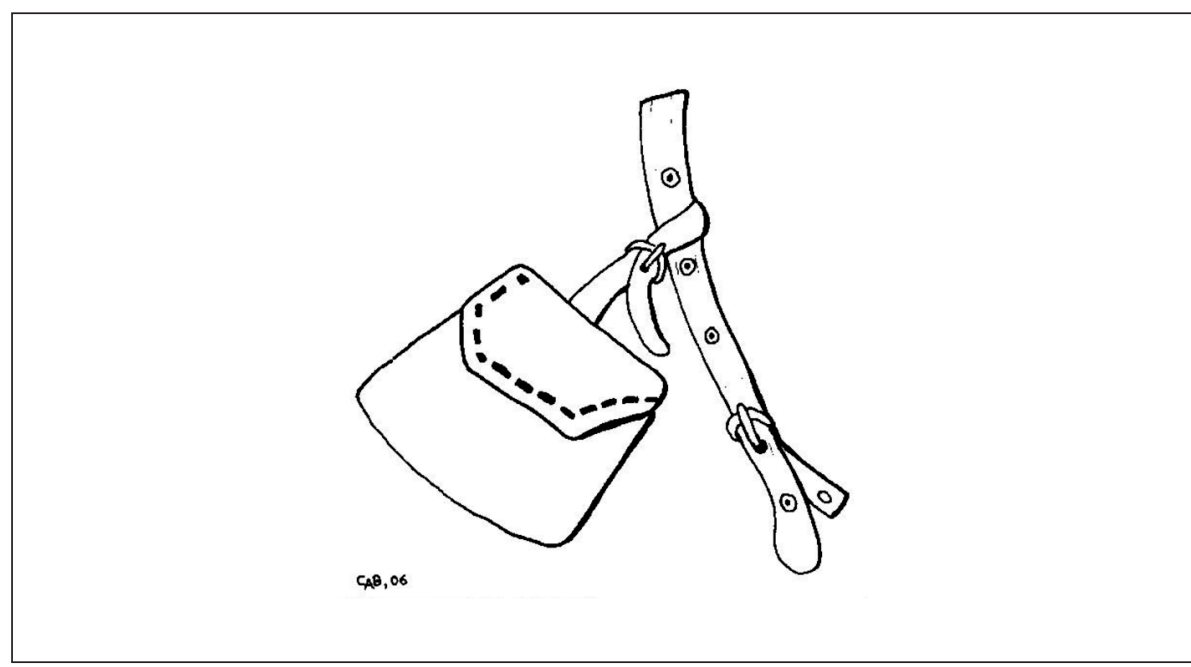

Fig. 3. Bossa d'home (Joan Reixach, m. v. 1492, Escenes de la passió, Museu de Belles Arts, València, detall).

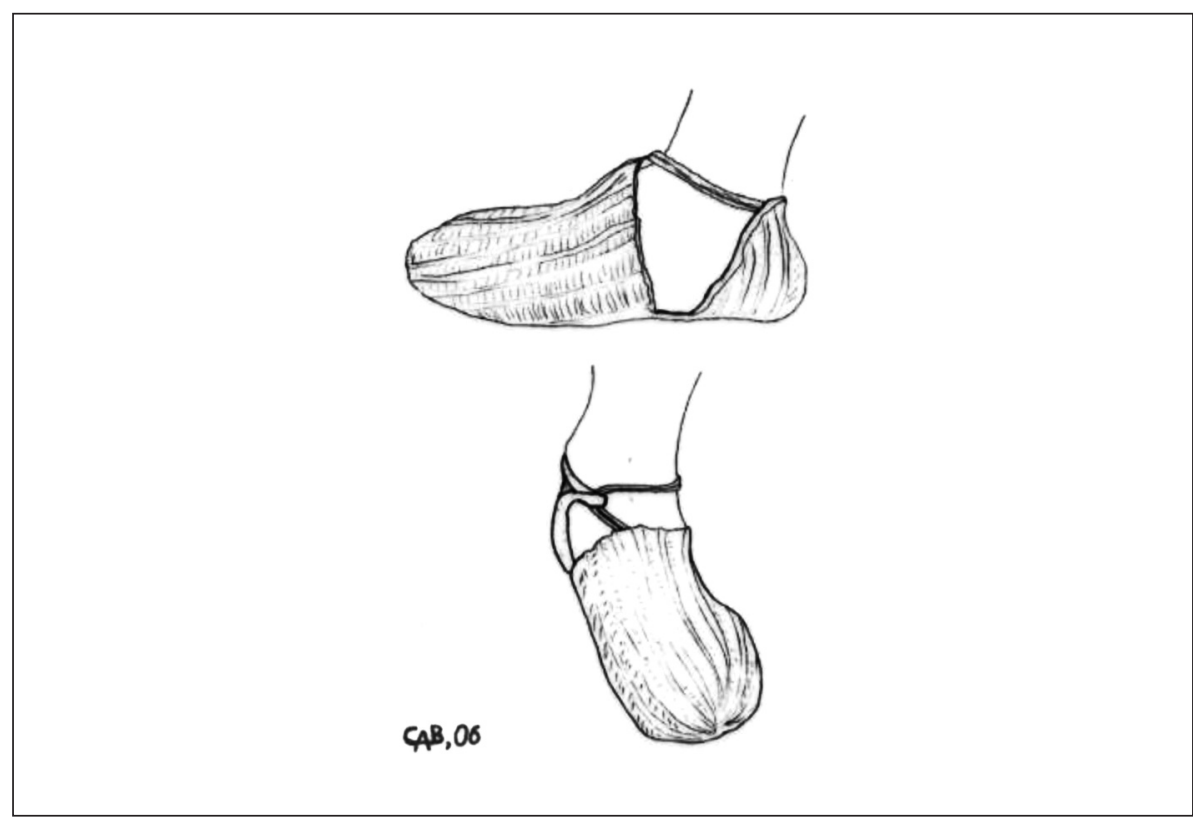

Fig. 4. Espardenyes (Francesc Ribalta, 1565-1628, San Isidro Labrador, Museu de Belles Arts, València, detall). 
Calça $<$ klsa $>$. Aquesta roba interior, que cobria el peu i la cama (de vegades arribava fins la cintura), només es menciona en els textos romànics consultats de data tardana: "calçes y çabates y tapins" (ARV, Clergat, llig. 749 caixa 1949-1950 [any 1583]). Segons un testimoni, una dona va simular que es lligava "la atapierna" per a amagar "en la calça" quelcom que després li trobaren "entre la carne y la calça" (AHN, Inq. llig. 554/21 i llib. 938, f. 169 [any 1602]). Encara que la font no indica de quin teixit estaven fetes, segons BERNIS (1979: II, s.v.) era costum morisca usar-les de lli. Se cita en un document àrab del $1587<$ klsa bawilī sindiruxūx $>$ "calces velles cendroses" (LABARTA, 1982: 151, 10r; BARCELÓ \& LABARTA, 2009, doc. 140).

Camisa. Era un cap de vestir interior, portat per homes, dones i xiquets: "dos camises envetades de seda negra"," una camisa e bragues de lenç", "dos camises de lli oldanes", (FERRER I MALlOL, 1987: doc. 102 [any 1372]) "camisa" (ARV, Mestre Racional 9568, f. 46v [any 1403]), "una camisa nova de chic" (BARCELÓ, 1984: 107 [any 1585]). Les de les dones podien tenir o no mànegues "camisa morisca sin mangas" (AHN, Inq. llig. 554/18 [any 1602]), "camisa nova, sense cabes ni punyets" (BARCELÓ, 1984: 107 [any 1585]). Es portava sobre la carn i es cobria amb el 'sayo' o 'saya' (AHN, Inq. llig. 554/ 4 [any 1575]; AHN, Inq. llig. 555/21 [any 1602]). N'hi havia de seda de colors, ratllades i brodades: "dos camises llistades" (BARCELÓ, 1984: 106 [any 1497]), "camisa obrada de seda negra, de dona", "camisa de dona obrada de seda de grana" (BARCELÓ, 1984: 108 [any 1585]), "camisa limpia labrada de grana" (AHN, Inq. 1lib. 938, f. 77 [any 1599]). Als processos inquisitorials es fa sovint referència al costum morisc de rentar-se i canviar-se de camisa per a fer l'oració musulmana.

Capa $<\mathrm{kba}>$. La portaven tant les dones com els homes, sense distinció. Es diu d'uns moriscos que "dormían embueltos con sus capas" (AHN, Inq. llig. 550/11 [any 1602]). Al segle XVI sembla que eren de color fosc o burell: "una capa negra usada molt", "una capeta parda vella" (BARCELÓ, 1984: 107 [any 1585]); però al segle XV eren d'altres tonalitats, com ara "una capa blava" que comprà l'alfaquí de la moreria de Sogorb (AMS, Justícia 153, f. 43v [any 1465]). Algunes portaven una mena de caputxa o sobre muscle: "la capilla de la capa" (AHN, Inq. 1lib. 918, f. 206 [any 1600]). En un text del 1587 es troba la forma <qabarusā> (LABARTA, 1982: f. 11r; BARCELÓ \& LABARTA, 2009, doc. 140) que pensem pot interpretar-se com "capa rossa" o "caperussa". Un text del 1587 esmenta una "capa $<\mathrm{kbā}>$ " i assenyala a més que és blau cel i vella (LABARTA, 1982: 151 f. 10r; BARCELÓ \& LABARTA, 2009, doc. 140).

Capell. És el nom d'un tipus de cubrecap que duien alguns homes en època mudèjar abans d'introduir-se el nom castellà de 'sombrero' (vegeu s.v. més avall). Un alfaquí d’Eslida portava “capell” (FERRER I MALLOL, 1987: doc. 102 [any 1372]).

Cint. Un mercader milanés que visità la moreria de València al començament del segle XVI va ser testimoni de com, a la mesquita estant, els mudèjars "butavano il cintto in terra, perchè dicono che quando si nomina Dio non 
si debe tenere adosso dinari o altra cosa sporcha, come poteria essere nel cintto" (MONGA, 1985: 145). Consta que els homes portaven "correja" (FERRER I MALLOL, 1987: 317, doc. 102).

Coll $<$ tawq $>$ / <twq $>$. Els documents en què s'esmenta indiquen que són de seda: "un coll de seda" (BARCELÓ, 1984: núm. 151/7 [any 1514]), "un coll de seda d'alcandora d'home" (BARCELÓ \& LABARTA, 1985: 65 / 67, 1. 22; BARCELÓ \& LABARTA, 2009, doc. 74 [any 1559]). Evidentment es tracta de colls postissos per a les camises o alcandores, com recull Alc. s.v. "collar de vestido <táuq>" i "cabeçón de camisa <táuq>".

Cosset. Podria tractar-se de la roba de dona que Carmen Bernis descriu sota la veu "cos". Segons aquesta historiadora (1979: II, 80-81), el cos seria una peça interior que podia tenir o no mànegues. Només el tenim documentat en dues ocasions, però es tracta clarament d'una peça externa: "cosset d'estamenya scarlat" (ARV, Batlia 329, f. 631 [any 1513]), "cosset de vellut negre, ab ses mànegues ab randes de or" (BARCELÓ, 1984, 108 [any 1585]). Podria ser el mateix que les fonts anomenen "cuerpo" en castellà: "un cuerpo de rasso carmessí con sus mangas" (BARCELÓ \& LABARTA, 1985: 69 [any 1563]) i "corpiño" també: "un corpiño de paño negro" (AHN, Inq. llig 935, caixa 2 [any 1607]).

Cota $<\mathrm{qt}>$. Segons BERNIS (1979: II, s.v.), la cota era una peça de roba femenina pareguda a l'hàbit mongil o faldilla i, per tant, un vestit exterior. Els textos als quals apareix només esmenten la "mija cota" per la qual cosa hom pot deduir que no arribava fins a terra. Una d'elles anava acompanyada d'una faixa: "mija cota tenada usada", "mija cota de tafatà negre, ab una faxa de vellut negre" (BARCELÓ, 1984: 107, 108 [any 1585]). Aquest vestit exterior que cobria des del coll fins als peus apareix com $<\mathrm{q} t>$ als textos àrabs i és usat tant per homes com per dones. Alc. documenta "mongil <cóta>" i "cota de malla <cóta min zarád>". Un document del 1587 esmenta "una cota blau cel de drap en samit grana" (LABARTA, 1982: f. 3r; BARCELÓ \& LABARTA, 2009, doc. 140). En altres documents: "un vestit de seda, és a dir mitja cota $<$ mjqwța $>$ de samit, amb un tarí d'or al coll" (VILA, 1933; BARCELÓ \& LABARTA, 2009, doc. 80 [any 1568]), "mitja cota $<$ mājqț > de jamelot" (BARCELÓ \& LABARTA, 2009, doc. 148 [any 1590]).

$<$ al-quțilā> . Potser és un diminutiu del romànic "cota". La trobem a un text del 1587 (LABARTA, 1982: f. 11r; BARCELÓ \& LABARTA, 2009, doc. 140).

Cuerpo. Vg. "cosset".

Devantal. L'usaven tant els homes artesans com les dones; al 1446 se cita "un devantal rexat" d'un sabater (BARCELÓ, 1980: 61). En una ocasió es diu que és de "fil, ab llistes grogues" (ARV, Batlia 329, f. 631 [any 1513]). També s'esmenta "un debantal de lana listado" (AHN, Inq. llig. 935/2 [any 1607]). Als processos inquisitorials pot observar-se com les morisques eren sorpreses a sa casa en "devantal" (AHN, Inq. llig. 554/19 [any 1602]; AHN, Inq. 1lib 938, f. 263 [any 1604]). 
Esparteñas $<$ bulga $>$. Aquest calcer, conegut també per alborga, era molt paregut a l'alpargata. Se cita un morisc que en venia (AHN, Inq. llig. 551/31 [any 1577]). Eren unes sabates de llaurador fetes d'espart o cànem; "unas esparteñas de cáñamo" se citen entre la roba de casa d'una vídua morisca (AHN, Inq. llig. 935 caixa 2 [any 1607]). La forma àrab <bulga $>$ es troba documentada a un text del segle XVI (BARCELÓ \& LABARTA, 2009, doc. 120).

Faixa. A més d'un complement d'altres peces (vegeu "cota" i "faldetes"), aquesta banda de teixit era un accessori que homes i dones es posaven envoltant la cintura sobre el vestit exterior. El 1584 s' esmenta "la faxa" d'una dona (AHN, Inq. 1lib. 936, f. 375) i el 1599 es fa referència a "una faxa que traya çeñida" un morisc (AHN, Inq. 1lib. 938, f. 54).

Falda. Aquesta part de la roba femenina que cau des de la cintura s'esmenta amb certa freqüència als processos inquisitorials perquè era el primer lloc on les morisques amagaven papers o altres objectes que no volien que els descobriren. Així, ocultaven coses: "entre las faldas" (AHN, Inq. llig. 551 / 6 [any 1603]; AHN, Inq. llig. 554/ 19 [any 1602]), "baxo las faldas" (AHN, Inq. 1lib. 938, f. 241 [any 1604]), "debaxo las faldas" o "debaxo de sus faldas" (AHN, Inq. 1lib. 938, f. 355 [any 1604]; 1lib. 939, f. 13 [any 1609]), "traya la falda arremangada" (AHN, Inq. llig. 550/ 6 [any 1583]). Ja el 1477 l'Inquisidor Hernando de Talavera es referia a aquest costum de les serves morisques "que quando se ocupan en los servicios y oficios humildes, alzan y remangan las faldas de la saya porque no se les haya de ensuciar"' (BERNIS, 1979: II, 86).

Faldetes. Es corresponen amb allò que en castellà s'anomenava faldilla i que només era visible quan les dones s'alçaven la falda del vestit. La primera cita és del 1529: una dona llega "un brial i unes faldetes" (GARCIA-OLIVER, 2003: 129); el 1580 un home parla de "las faldetas de su mujer" (AHN, Inq. llig. 550/5). Una peça bén descrita és la que apareix a un inventari: "unes faldetes de filadís naranjat, ab una faixa de vellut carmesí" (BARCELÓ, 1984: 108 [any 1585]). S'esmenten també "unas faldetas de estameña azul" (AHN, Inq. llig. 935 caixa 2 [any 1607]).

Faltriquera. Aquesta bosseta que es penjava a la cintura només es menciona en relació a homes. Es documenta per primera vegada el 1593 i fins el 1609, amb les formes castellanes faltriquera i fratiquera (AHN, Inq. 1lig. 551/3; llig. 551/39; 1lib. 937, f. 551; 1lib. 939, f. 17).

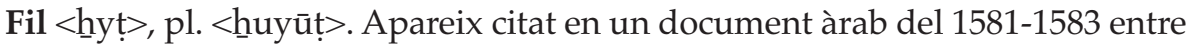
les coses que s'han pagat per costura i materials de sastreria i pareix tenir sentit genèric (LABARTA, 1994: 6v; BARCELÓ \& LABARTA, 2009, doc. 132). Un altre text, del 1583, diu que els extrems d'una alvacaïa o cubrecap estaven brodats en fil d'or (LABARTA, 1983: 73; BARCELÓ \& LABARTA, 2009, doc. 133).

Gipó / Jubón. Encara que es tractava d'una peça de vestir masculina, que es documenta ja el 1446 ("un gipó d'estamenya blava”, BARCELó, 1980: 61), apareix el 1583 entre les despeses de la tutela de dues xiquetes: "una alna 


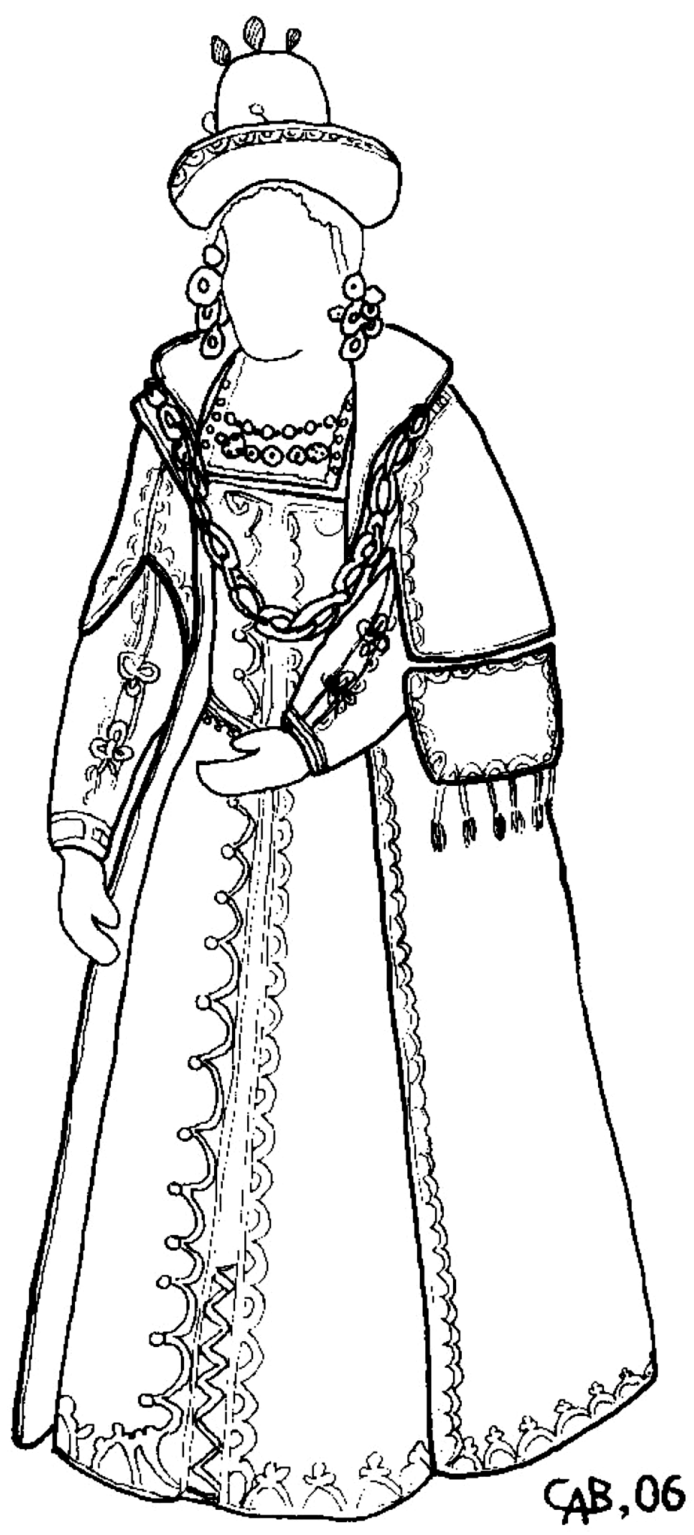

Fig. 5. Dona morisca amb vestimenta a la "cristiana" (inspirat a la sèrie pictòrica Embarque de los Moriscos, 1612-1613, Col-lecció Fundación Bancaja, València). 
de raxa negra... per a dos gipons" i "un gipó" (ARV, Clergat, llig. 749 caixa 1949-1950). N’hi havia de diferents tipus de teixit: "un gipó de orlanda de home usat" (BARCELó, 1984: 107 [any 1585]), "un xubón de lienço blanco con unas mangas postiças" (AHN, Inq. 1lig. 555/ 6 [any 1591]). En alguns casos s'emprava la buata del folre per a amagar-hi coses, com ara uns papers que es van trobar "dentro del jubón" d'un morisc, "enbuelta en algodón del jubón" (AHN, Inq. llig. 554/17 [any 1602?]). En una ocasió s'identifica aquesta peça amb un altre vestit exterior: "el sayo o jubón" (AHN, Inq. llig 551/39 [any 1600]).

Greguescos. Aquest tipus de pantalons amples i curts eren una peça per a home. Els que portaven els moriscos eren de drap de llana. Es mencionen el 1602 "greguescos verdosos", "dos greguescos de paño pardo" i "greguescos de paño verde" (AHN, Inq. llig. 554/18).

Jaquet $<$ jaqit $>$ / <jqīt $>$. Roba exterior d'home o de dona, que cobria el cos sense baixar de la cintura. N'hi havia amb mànegues i sense (LABARTA, 1994: f. 2v; BARCELÓ \& LABARTA, 2009, doc. 132 [anys 1581-1583]) a més de fets amb diversos materials, com ara "un jaquet de vellut" a l'inventari dels béns de l'eixovar d'una morisca difunta d'Albalat de Tarongers (BARCELÓ \& LABARTA, 2009, doc. 154 [any 1593]), "un jaquet <jqīt > de samit" (VILA, 1933; BARCELÓ \& LABARTA, 2009, doc. 80 [any 1568]) i un altre "jaquet $<$ jqt $>$ de samit" (BARCELÓ \& LABARTA, 2009, doc. 148 [any 1590]).

Llançol. Encara que podia referir-se al drap de llit, aquest mot també designava un tipus de manto, fet generalment de teixits lleugers, que portaven homes i dones: "dos parells de llançols" (AMV, Lletres del Rei, g3-2 [any 1351]); "dos linçols xiquets oldans ab listes vermelles als caps", "dos linçols de lli morisch oldans", "dos troços de linçols vells la un blanch e l'altre vermell", "un lançol de lli morisch obrat al cap de seda vermella e negra" (FERRER I MALLOL, 1987: doc. 102 [any 1372]); “dos lançols, hú de cap per a mora e altre ab dos listes, la una vermella e l'altra negra", "un parell de lançols de dos teles" (BARCELÓ, 1980: 60 [any 1446]); "un llençol nou de lli, gran"' (BARCELÓ, 1984: 108 [any 1585]).

Loba. Vg. "ropa" i "tafetà".

Mànegues / Mangas. S'utilitzaven com un accessori dels vestits, per a cobrir la camisa. Així s'esmenten als inventaris, com a objectes independents: "unas mangas de terciopelo negro guarnecidas con una trença de oro" (BARCELÓ \& LABARTA, 1985: 69 [any 1563]), "unes mànegues de vellut" (APN, Prot. F. Sanchis [any 1604]) o "unas mangas postiças" d'un gipó (AHN, Inq. 1lig. 555/6 [any 1591]).

Manto $<$ al-mnt $>/<$ rāda $>$, <a_rada $>$. A l'inici d'aquest treball ja hem vist un exemple del seu ús el 1372: "un manto de burell negre squinçat" (FERRER I MALLOL, 1987: doc. 102). S'esmenta també el que portava un mudèjar (BARCELÓ \& LABARTA, 2009, doc. 20 [any 1492]). A uns comptes del 1587 es fa esment d'"un manto < rāda> de ras", posat en penyora; "el manto 
$<$ a_rada>" fou recuperat després (LABARTA, 1982; BARCELÓ \& LABARTA, 2009, doc. 140, 7r [any 1587]).

Marlota. Aquesta coneguda peça femenina de vestir morisca -molt usada a la zona de Granada (vegeu Alc. s.v. "saya assi $<$ mollóta, malálit $><$ pollóta, palálit>”)- només es documenta una vegada, el 1604, en l'eixovar d'una morisca de la Vall d'Uixó: "una marlota de vellut guarnida ab randes de or" (APN, Prot. F. Sanchis). Va ser usada també pels cristians, que a València la distingien d'altres amb l'apel-latiu morischa, com consta a alguns inventaris del segle XV: "una morlota morischa de seda de diversos colores" (ALCOVER \& MOLL, s.v.).

Mocador. Només se citen "dos mocadors, lo hun obrat de negre i lo altre de naranjat" en un dels inventaris consultats (BARCELÓ, 1984: 108 [any 1585]). Segons BERNIS (1962: 63), podria tractar-se dels vels amb què les dones es tapaven la cara quan viatjaven.

Roba $<\underline{\text { taw }} b>/<\underline{\text { twb }}>$. Aquest terme genèric s'utilitza als textos més antics per a referir-se a la tela, drap o llenç (BARCELó, 1984: núm. 28/2 [any 1368]). A la documentació morisca pareix significar "vestits / peça de roba” (LABARTA, 1983: 86; BARCELÓ \& LABARTA, 2009, doc. 147 [anys 15801590]). En un cas s'especifica que es tracta d'una toca $<$ țawb harīr twq $>$ (BARCELÓ, 1984: 204; BARCELó \& LABARTA, 2009, doc. 57 [circa any 1525]) i en un altre "un vestit de seda, és a dir mitja cota de samit, amb un tarí d'or al coll" (VILA, 1933; BARCELó \& LABARTA, 2009, doc. 80 [any 1568]). Alc. recull aquesta paraula sota "mongil vestidura de monge", "vestidura del cuerpo solo", "veste lo mismo es que vestidura", "abito".

Ropa. Es tractava d'un peça exterior, que es portava sobre la 'saya' o 'sayo'. BERNIS (1979: II, s.v.) assegura que era una peça de luxe. Encara que podia ser d'home o de dona, només en tenim una referència a l'inventari dels béns de Victoria Filomena, rica morisca de Benissanó, on se'n citen dues: "una ropa de terçiopelo negro" i "una ropa grande de tafetán girasol que la llaman loba, con alas, guarneçida de terçiopelo de grana" (BARCELÓ \& LABARTA, 1985: 69 [any 1563]).

Ropilla. Era una peça molt curta que els homes portaven sobre el gipó i s'anomenava també ropeta (BERNIS, 1979: II, 119). Només se cita respecte a homes i una d'elles portava una bossa cosida "por la parte de dentro" (AHN, Inq. llig. 555/21; llig. 554/18; 1lib. 938, f. 169 [any 1602]).

Sabata. La denominació àrab del calcer, com ho atestigua Alc. "calçado común <çapát çapápit>" i els documents moriscos, és <zabat > / <sabat > / <sabit > , pl. <sababat > / <sababit > / <sababit > / <zababit > (cfr. BARCELÓ \& LABARTA, 1985: 67-68 [any 1573?]; BARCELÓ, 1984: núms. 205 i 206/14 [any 1594]). L'any 1583 trobem "calçes y çabates y tapins" (ARV, Clergat, llig. 749 caixa 1949-1950). Segons el testimoni de l'any 1573 la sabata es confeccionava amb sola fina $<$ satha $>$ (terme que hom troba en Alc. com "suelo como quiera"). Segons les ordinacions del gremi de sabaters de 


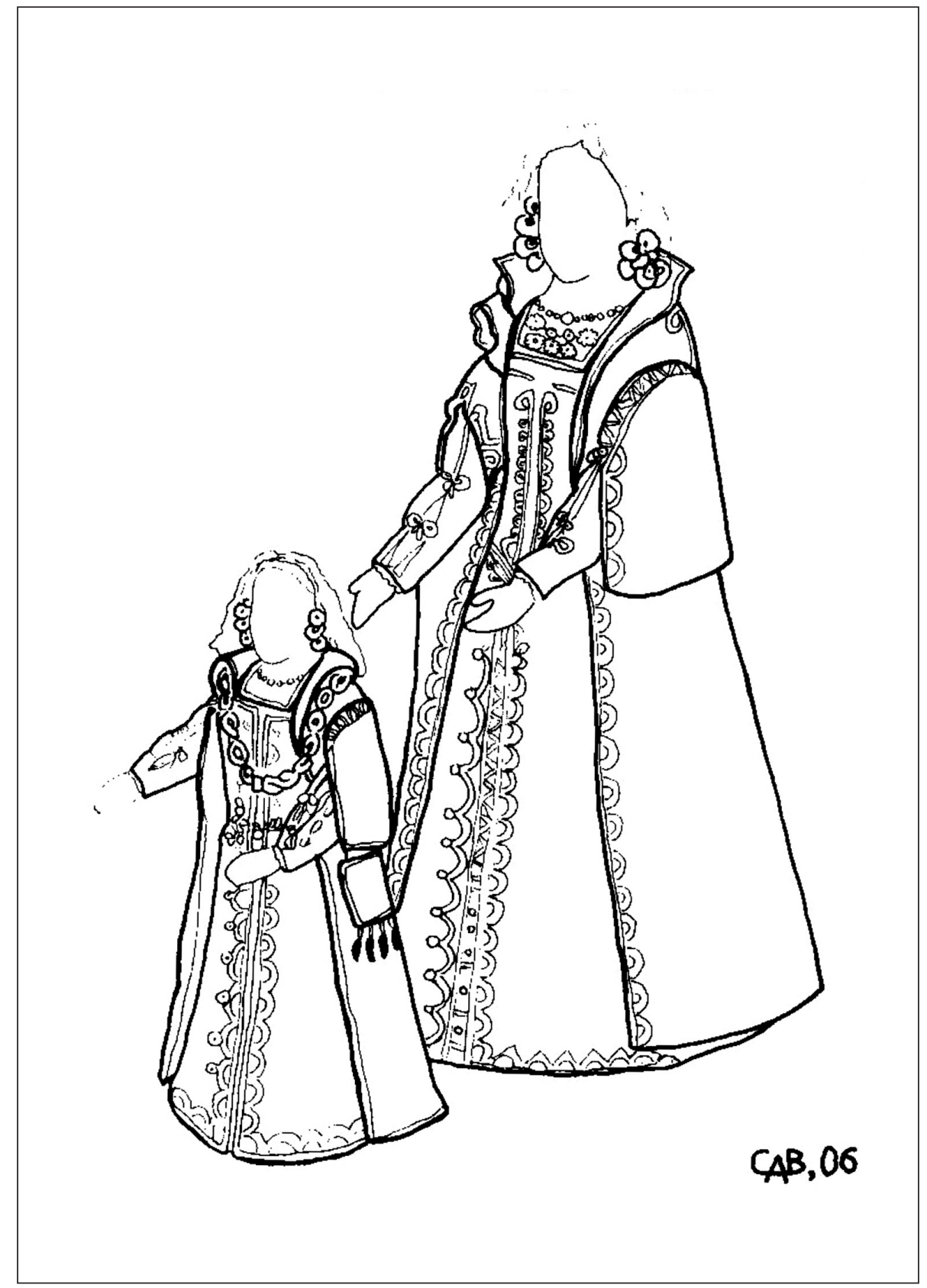

Fig. 6. Grup de dona i xiqueta vestides "a la cristiana" (inspirat a la sèrie pictòrica Embarque de los Moriscos, 1612-1613, Col-lecció Fundación Bancaja, València). 
València del 1513 estava prohibit obrar "çabates de dos soles que aquelles tal çabates no sien cosides menys de dos costures, ço és, la una en la jus sola e l'altra en la sobre sola, e que la jus sola sia de cuyro de bou e la sobre sola, millorant aquelles dites çabates de dos soles e la girada, sia de cordovà" (PILES, 1959: 151). Sembla que el text del 1573 al·ludeix a aquest tipus de sabates quan empra el terme $<$ jujulat $>$, és a dir jus-solat o amb una sola inferior. Una taula del 1612 custodiada a l'arxiu municipal de València (PILES, 1959: làm.) mostra les diferents peces de què es composava el calcer. La mesura de la sola es comptava -i encara es comptamitjantçant un cartabó dividit en punts. Al text ja esmentat (BARCELó \& LABARTA, 2009, doc. 85) s'assenyala aquesta mesura amb la veu $<$ bunt $>$ pl. $<$ abnit $>$, testimoniada també a Alc. com a "punto que cierra la sentencia". Dels deu parells de sabates que cita el text, sis són de 5 punts, un de 6 i dos de 7. No s'indica la mesura de la sabata de "la xiqueta" però, com a referència, poden citar-se les ordinacions de la ciutat de Logroño del 1607, on s'explica que les sabates per a xiquets no arribaven més enllà de quatre punts, mentre que les sabates dels adults (homes i dones) ultrapassaven els cinc (RAMírEZ, 1981: 39). Pel que fa al material, totes les sabates esmentades al document del 1573 són de setí ras (vegeu ací “setí").

Saboyana. Es tracta d'una faldilla que es portava com a peça exterior i era similar a la basquinya; estava oberta pel davant. Només s'esmenten entre la roba de dues riques morisques: la filla de Vicent Baia, de Benifairó de Valldigna, i Victoria Filomena, de Benissanó. La xiqueta tenia "una saboyana de vayeta" (ARV, Clergat, llig. 749 caixa 1949-1950 [any 1583]); la dona, "una saboyana de paño verde guarneçida de terçiopelo, a la cristiana fecha" (BARCELÓ \& LABARTA, 1985: 69 [any 1563]).

Saquillo / Saquet <uxqayr $>$. Era un altre complement que, com la bossa, es portava lligat al cos. No sabem si l'utilitzaven indistintament homes i dones. Se cita, parlant d'un morisc, "un saquillo de cuero de aluda" (AHN, Inq. 1lig. 554/7 [any 1603]). El sinònim àrab de "sac" és, segons Alc. i Voc. <xikāra >. A un text àrab s'esmenta el seu diminutiu <uxqayr $>$, és a dir un saquet on un home portava els diners que li furtaren (BARCELÓ \& LABARTA, 2009, doc. 20 [any 1492]).

Saquo. Només trobem "un saquo vaquero" esmentat a l'inventari d'un artesà mudèjar de la moreria de València (BARCELÓ, 1980: 60 [any 1446]). Sobre les seues formes i altres detalls, vegeu Alcover \& MolL.

Saraüell < sarawil >. Es tracta d'una peça interior, tant de dona com d'home, ben coneguda. Al despullar una morisca per al turment aquesta restà "en camisa y çaraguelles" (AHN, Inq. llig. 548/3 [any 1589]). Es portaven sobre la carn i cobrien de la cintura fins els peus. De vegades se li dóna també aquest nom a un vestit exterior masculí com el "calzón de negrilla" que a les terres valencianes es continua emprant per a cobrir els saraüells. Se citen el 1585 "uns sarahuells negres de drap, forrats de tela" (BARCELÓ, 1984: 107) que pot- 
ser es portaven els dies de festa o de solemnitats. La forma $<$ srwl $>$ sense vocals es pot llegir <sirwal>, que és el nom àrab d'aquest vestit en singular. El testimoni d'Alc. "bragas" <çaráguil çaraguilít> (on el plural és usat com a singular) i el fet que en alguns documents trobem el mot vocalitzat < sarawil > ens fa pensar que tal vegada aquesta fóra la forma usual per al singular, com succeeix actualment amb saraüells i pantalons. El 1587 se citen uns "saraüells pardillos sense trinxa" (LABARTA, 1982: 155; BARCELÓ \& LABARTA, 2009, doc. 140) i el 1581-1583, sense més aclariments, "uns saraüells" (LABARTA, 1994: 2v; BARCELÓ \& LABARTA, 2009, doc. 132).

Saya $<$ xaya $>/<$ xayā $>$. Aquest era el vestit que portava la major part de les dones de qualsevol condició. Es duia ajustada sobre la camisa i solia estar folrada (BERNIS, 1979: II, 120). N'hi havia de camelot o de drap de llana; entre les primeres se citen "unes sayes de chamellot usades de carmesí ab barret de bellut" (ARV, Batlia 329, f. 631 [any 1513]), a més de "una saya de chamelote carmessí guarnecido con terciopelo negro" i una altra "saya de chamelote amarillo, guarnecido con terciopelo carmessí o de grana", ambdues de Victoria Filomena (BARCELÓ \& LABARTA, 1985: 69 [any 1563]). A aquesta mateixa morisca pertanyia un "saya de paño verde guarneçida con vellut verde". La 'saya' també es podia recollir enfaldada i en els plecs s'amagaven objectes. Una morisca ocultava quelcom en la "enfaldadura de una saya que tenía enfaldada" (AHN, Inq. 1lig. 550/11 [any 1602]). Aquesta peça no s'havia de portar molt apretada segons revela el següent testimoni d'un escorcoll realitzat per part d'un guàrdia a una morisca, doncs "éste [...] la halló junto a las carnes debaxo del sobaco tenía un bulto y éste metió la mano y la dicha mujer afloxó y se lo dejó caer el dicho bulto entre las piernas y baxándole éste la saya se cayó con la mesma saya en el suelo y ella se puso de pies sobre ello y mirando éste, la dicha muger se halçó la camisa diçiendo: «mira como no tengo nada» y éste alçó la saya del suelo y halló debaxo el libro" (AHN, Inq. llig. 553/13 [any 1585?]). El mot àrab està amplament documentat als textos de Granada i al regne de València se'ns descriuen dos el 1591: una de drap de color morat i una altra d'estamenya groga (LABARTA, 1983: 82; BARCELÓ \& LABARTA, 2009, doc. 151). Apareix també el 1559: "una faldeta de grana, amb trepa de seda negra" (BARCELÓ \& LABARTA, 1985: 65 /66, 1. 5; BARCELÓ \& LABARTA, 2009, doc. 74).

Sayo. Era la peça de roba masculina més habitual i es portava sobre el gipó. Apareix citat el 1446 "un sayo blau" (BARCELÓ, 1980: 60). Com ja hem dit a l'apartat dedicat al gipó, en ocasions substituïa aquest; així un morisc amagava una cosa "entre la camisa y el sayo" (AHN, Inq. llig. 555/21 [any 1602]). El folre d'alguna d'aquestes peces servia també d'amagatall: "en el aforro del sayo" (AHN, Inq. llig. 550/25 [any 1581]; 1lib. 918, f. 442 [any 1608]). Tal vegada pel fet d'estar folrat era necessari "espulgarle" (AHN, Inq. 1lig. 550/ 25 [any 1581]). La poca qualitat d'un altre explica que s'esquinçara amb un ganivet despuntat (AHN, Inq. llig. 554/17 [any 1581]). 
Sombrero $<q_{n z}^{\prime}>/<q u \bar{n} z^{\prime}>/<$ kinza' $^{\prime}$. Les descripcions que trobem als inventaris no especifiquen si és per a home o per a dona. És possible que tinguès ala el que es descriu com "un sombrero de vellut ab una randa de or y cordellares de or" (BARCELÓ, 1984: 107 [any 1585]). No és fàcil determinar, però, si sota el "sombrero" es cobrien les dones els cabells amb algun tipus de toca. Dels que se citen als processos inquisitorials no se'n dóna cap particularitat; tots eren d'home (AHN, Inq. 1lib. 936, f. 346 [any 1583]; 1lib. 939, f. 12 [any 1609]). Als textos àrabs només apareix la forma genèrica del cubrecap o capell, sense detalls sobre el material de què estava fet ni sobre la seua forma: < qūnz'> (LABARTA, 1994: 2r-v; BARCELÓ \& LABARTA, 2009, doc. 132 [anys 1581-1583]) <qnz'> (BARCELÓ \& LABARTA, 2009, doc. 19 [any 1490]; BARCELÓ \& LABARTA, 2009, doc. 148 [any 1590]); <kinza'> (BARCELÓ \& LABARTA, 2009, doc. 120 [segle XVI]). L'únic testimoni del teixit de què estava fet és de l'any 1568: "un capell de samit" (VILA, 1933; BARCELÓ \& LABARTA, 2009, doc. 80).

Talegueta $<$ tu'ayliqā $>$. La forma diminutiva àrab de la veu coneguda "talega" es refereix a un saquet o bosseta on portar diners o coses menudes. Al document del 1587 on ix s'indica que és <samiyā $>$, val a dir "blau cel" (LABARTA, 1982: 155; BARCELÓ \& LABARTA, 2009, doc. 140).

Tapins. Calcer en forma de sandàlia amb sola gruixuda, generalment de suro: “calçes y çabates y tapins" (ARV, Clergat, llig. 749, caixa 1949-1950 [any 1583]).

Tela verd. Se cita <talabrdifitul?>, que interpretem com "tela verd de felro?", en un document del segle XVI que recull les despeses d'un camperol (BARCELÓ \& LABARTA, 2009, doc. 120).

Toca / Toquilla $<$ țwq $>$ / $<$ farha $>$. Aquesta peça, que s'emprà com capell o turbant (cfr. BERNIS, 1979: II, 27-28), s'esmenta el 1446 entre els béns d'un home: "una toqua, los caps blaus"; aquestes puntes serien les que quedarien penjant després de format el turbant (BARCELÓ, 1980: 60). També les portaven les dones, puix que apareix en un contracte de noces on es dóna a la núvia "una peça de roba de seda, toca $<$ twwq $>$ en llengua vulgar" (BARCELÓ \& LABARTA, 2009, doc. 57 [circa any 1525]).

S'esmenta una <farha > el 1591 (LABARTA, 1983: 82; BARCELÓ \& LABARTA, 2009, doc. 151). Aquesta peça femenina per al cap és recollida per Alc. com "toca sagrada de monja" <farka $>$, però no diu en què es distingia de la que portava la dona laïca.

Pel que fa a la toquilla, en un procès contra un morisc de Iàtova es diu que s'havia alegrat públicament perquè un alfaquí "le havía dado una toquilla" (AHN, Inq. 1lig. 551/37 [any 1608]; 1lib. 939, f. 60 [any 1609]).

Torcamà <turqamā>. Aquest sinònim d'eixugamans només apareix a un document de c. 1559 (BARCELÓ \& LABARTA, 1985: 65/66, 1. 16; BARCELÓ \& LABARTA, 2009, doc. 74). Podria tractar-se de roba de casa.

Tovalla $<$ mandil $>$, pl. $<$ manidil $>$. Era una mena de turbant que portaven els homes. Durant el període mudèjar els musulmans estaven obligats a por- 
tar al cap una "tovallola blava" com a signe distintiu (BARCELÓ, 1984: 85). De vegades se citen sense indicació de ser roba de vestir d'home, com ara el 1372 on es parla de "unes tovalles morisques ab cotó vermell i blau" (FERRER I MALlOL, 1987: doc. 102) i en un inventari de 1446 s'esmenten "unes tovalles chiques, de dos alnes pasades" (BARCELó, 1980: 60). En altres textos es fa referència a "tovalletes", "una tovallola" i "una tovaja de red" (BARCELÓ, 1984: 107 [any 1585]; AHN, Inq. llig. 554/18 [any 1602?]). Un document àrab de 1559 cita tovalles o <manidil>: "un parell de tovalles escacades, cadascuna de dues alnes i mitja", "dues tovalles de cinc alnes i mitja", "tres tovalles esquinçades" (BARCELÓ \& LABARTA, 1985: 65/67, 1. 23, 24, 25; BARCeló \& LABARTA, 2009, doc. 74). Alc. ofereix l'equivalència "tovajas <mandíl manídil >”. Podria tractar-se d'un cubrecap però també de roba de casa.

Vel / Velo. Peça de vestir o complement de la indumentària femenina. Se cita a l'inventari dels béns de la casa d'un ric mercader de la Valldigna: "un vel vermell, ab caps de or" i "tres vels, lo hu de tela de or, lo altre de seda naranjada y lo altre de seda blanca" (BARCELÓ, 1984: 107, 108 [any 1585]) i entre la roba de casa d'una morisca: "un velo y una camisa, todo muy viejo" (AHN, Inq. 1lig. 935/2 [any 1607]).

Vestidura o Vestit $<$ libās $>$. Terme genèric que Alc., tot donant l'equivalent àrab <libíç $>$, recull sota els epígrafs "abito vestido", "vestidura generalmente", "vestidura enforrada", "vestidura del cuerpo solo", "vestidura real", "vestido qualquiera", "trage de vestido". S'esmenta a un acta de noces (VILA, 1933 i BARCELÓ \& LABARTA, 2009, doc. 80 [any 1568]). Un altre document àrab cita el drap $(<$ malf $>$ ) per a la seua confecció (BARCELÓ \& LABARTA, 2009, doc. 73 [any 1557]).

Zurrón. Aquestes bosses grans que eren utilitzades pels camperols i pastors apareixen entre els béns de moriscos processats per la Inquisició en dues ocasions. D'un, se'n diu que estava "atado, que era de cuero y tenia enzima un pedaço de lienço blanco" (AHN, Inq. llib. 936, f. 379 [any 1584]; llig. 554/7 [any 1603]).

\section{JOIES, METALLS PRECIOSOS I ALTRES OBJECTES DE VALOR}

Albolares. Eren unes arracades; les que tenim documentades són, quasi totes, d'or: "un orellal amb dues alboralles i tres grans d'or", "dues alborelles" (GARCIA-Oliver, 2003: 38, 129 [anys 1525, 1529]). Entre les joies de Victoria Filomena hi havia "unas arracadas albulares a la morisca de oro" (BARCELÓ \& LABARTA, 1985: 69 [any 1563]); també a l'eixovar d'una morisca de la Vall d'Uixó es parla d'"unes albolares de or" (APN, Prot. F. Sanchis [any 1604]). Probablement el que es descriu en 1585 com "uns erbolaris ab sis erbolaris [sic]" (BARCELÓ, 1984: 107) faça referència a aquest tipus d'arracades. 


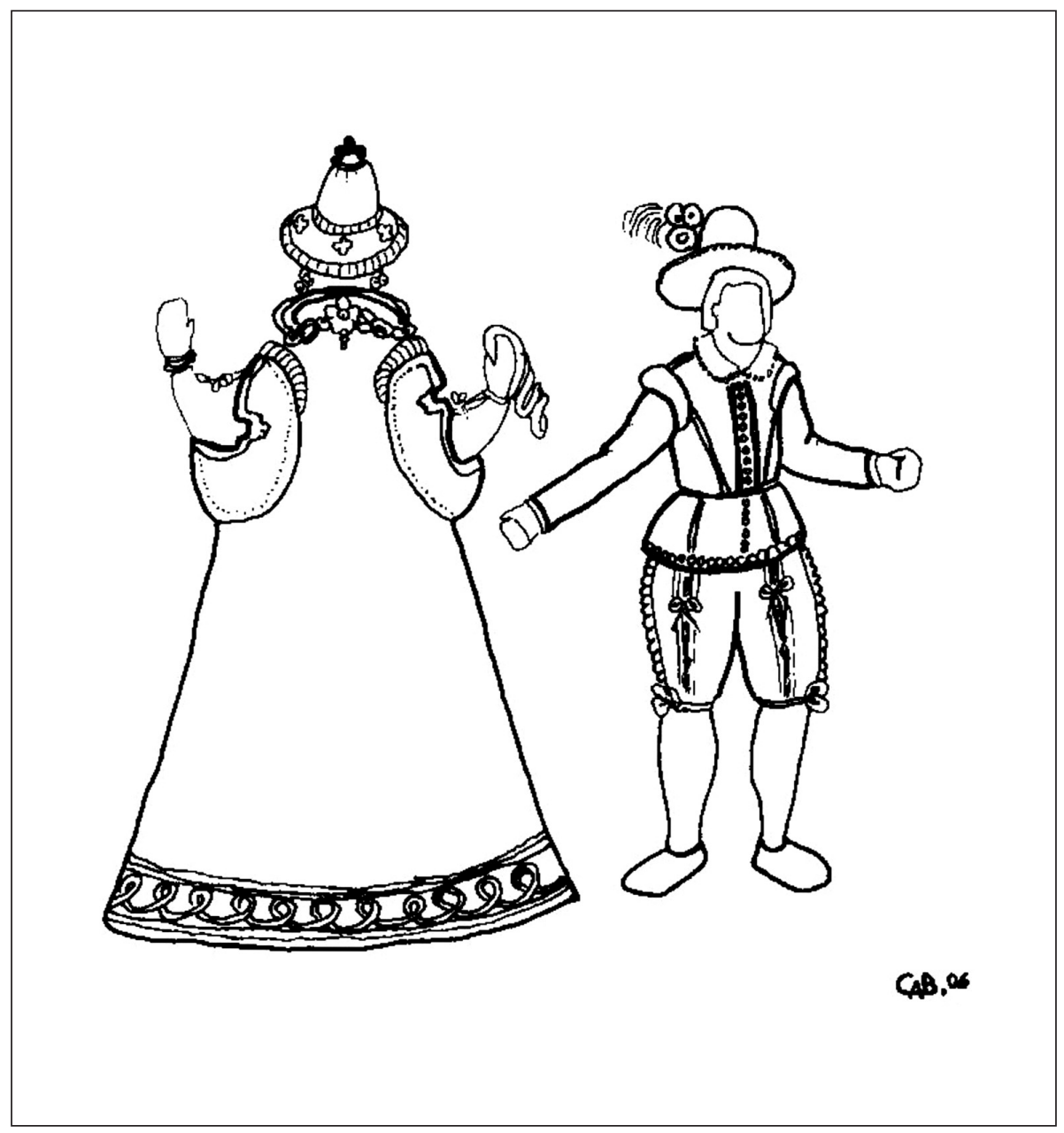

Fig. 7. Home i dona d'esquena, vestits "a la cristiana" (inspirat a la sèrie pictòrica Embarque de los Moriscos, 1612-1613, Col-lecció Fundación Bancaja, València). 
Alhait / Jayte. Un tipus de collar. En català aquest arabisme només es troba documentat a la Valldigna: "un alhait d'argent amb fils de perles petites penjants" (GARCIA-OLIVER, 2003: 38 [any 1525]). A Castella s'esmenta a inventaris de béns de morisques granadines; per exemple, al d'una d'Almeria s'hi diu; "un collar que se llama jayte” i "otro jayte de aljófar, con dos zarteles de aljófar" (MARTíNEZ RuIZ, 1967: 122 [any 1568]).

Aljòfar $<$ jawhar $>$ / <jwhr $>$. Tipus de perletes. N'hi ha abundants cites on, de vegades, apareixen soltes o bé incorporades a ornaments per al cap. Les cartes de noces citen només "aljòfar" (LABARTA, 1983: 64; BARCELÓ \& LABARTA, 2009, docs. 99, 148 [anys 1570-1580, 1590]). En altres s'hi al·ludeix pesades en unces: "mitja unça de perletes mitjanes", "dues unces de perletes", "dues unces de perletes mitjanes en preu i tamany" $i$ "mitja unça de perletes mitjanes” (LABARTA, 1983: 81; BARCELÓ \& LABARTA, 2009, doc. 151 [any 1591], 57 [circa any 1525], doc. 80 i VILA,1933 [any 1568], doc. 148 [any 1590]).

Ambre <'nābr $>$. Una rica morisca tenia un "collaret de perles menudes [...], ab quatre pedres d'ambre e quatre grans d'argent" (BARCELÓ \& LABARTA, 1985: 69-70 [any 1500]). En un text àrab del 1557 se cita "ambre" com a donatiu de noces (BARCELÓ \& LABARTA, 2009, doc. 73).

Anillo pl. $<\underline{\text { hwa }}$ tm $>$. El porta un morisc, però no se'n especifica de quina matèria era, ni quines eren les seues característiques (AHN, Inq. 1lib. 938, f. 360 [any 1607]). Els anells són en àrab $<\underline{h} w a \overline{t m}>$, com ara "un parell d'anells per als dits" que es regalà a una dona de Fanzara (BARCELÓ \& LABARTA, 2009, doc. 13 [any 1468]).

Argent $<$ fiḍā $>/<$ fida $>/<$ fidah $>$. Metall preciós de què es feren diverses joies. El 1372 s'esmenten "unes orelleres de argent" d'una dona d'Eslida (FERRER I MALLOL, 1987: doc. 102). En un eixovar de Fanzara es parla d'“un braçal de plata, ornat amb cinc unces" (BARCELÓ \& LABARTA, 2009, doc. 13 [any 1468]). En la Valldigna trobem: "un alhait d'argent amb fils de perles petites penjants", "un collaret format per deu cases de dos en dos, amb les seues pedres, setze grans d'or i quatre d'argent daurat", "dòmines de plata", "una cadena de plata amb dues tisoretes i una altra amb una mà" (GARCiA-Oliver, 2003: 38 [any 1525]). Hi han "unos cascaveles de plata e media luna con letras aràbigas" i "dos patenas de plata, en la una pintado el sol y en la otra una mano, con letras arávigas" (AHN, Inq. llib. 937, f. 227 i 235 [any 1590]). Als textos àrabs apareix el nom d'aquest metall de què estaven fets certs joiells, que no s'especifiquen (LABARTA, 1983: 87; BARCELÓ \& LABARTA, 2009, doc. 147 [anys 1580-1590]). Un inventari àrab esmenta una cullera i una nòmina fetes d'aquest metall (BARCELÓ \& LABARTA, 1985: 65/66, 1. 13-17; BARCELÓ \& LABARTA, 2009, doc. 74 [any 1559]), igualment que el "giseram" que citem més avall. De plata estaven fetes moltes "manilles" (Vg. s.v.).

Arracades $<$ raqadix $>/<$ qrt $>$. Les descrites a inventaris i eixovars són sempre d'or. Trobem: "unes arracades d'or" i el 1529 es llega a una dona 
mudèjar "unes arracades d'or amb perles" (GARCIA-Oliver, 2003:). (GARCIA-OLIVER, 2003: 128, 129 [any 1525, 1529]), "unas arracadas albulares a la morisca de oro", "unas arracadas de oro a la christiana", "unas arracadicas de oro pequeñas a la christiana" (BARCELó \& LABARTA, 1985: 69 [any 1563]) i "unes aracades o campanes" (APN, Prot. F. Sanchis [any 1604]). Com pot advertir-se hi hagué diferències entre les fetes "a la morisca" i "a la cristiana". Als textos àrabs pot aparèixer el mot català transcrit: "unes arracades < raqadix > d' or" (BARCELÓ \& LABARTA, 2009, doc. 89 [any 1576]); o el terme àrab: "dues arracades $<$ qrt $>$ per a les orelles, ornades amb perletes” (BARCELÓ \& LABARTA, 2009, doc. 13 [any 1468]). A la fig. 1 se'n poden observar dos exemplars d'argent, trobats en una excavació a la província de Castelló: una "anelleta" i una arracada amb la mà de Fàtima.

Axorca. Covarrubias, que estigué a València, explica s.v. axorcas: las que por otro nombre llamamos manillas, que son los cercos de oro o plata que se traen en las muñecas y junturas del braço y la mano [...] ay alguna diferencia, porque las manillas suelen ser redondas y retorcidas, las axorcas son anchas y quadradas y suelen estar adornadas con esmaltes, labores y pedrería (1611: 172). D'aquest tipus de braçalet s'esmenten dos exemplars entre els béns de Victoria Filomena, dona del mercader morisc Ferran de Benàmir, que es descriuen de la manera següent: "dos axorcas de oro a la christiana" (BARCELó \& LABARTA, 1985: 69 [any 1563]).

Braçal < hayt quṭūn $>$. El Voc. presenta l'equivalent llatí "armilla" per a aquest sintagma aràbic que també s'esmenta en una carta de noces, on hem interpretat: "un braçal de plata, ornat amb cinc unces" (BARCELÓ \& LABARTA, 2009, doc. 13 [any 1468]), però potser podria tractar-se d'un collar en lloc d'un braçal.

Bracerola $<$ msys $>$, pl. $<$ masiyis $>$. Dozy (s.v.), fent ús d'altres fonts, explica que són braceroles enormes, d'or o d'argent sense pedres, macisses i mal treballades, una mena de barres d'or o d'argent corbades. Apareixen a eixovars de morisques: "quatre parells de braceroles d' or" i "quatre [parells] de braceroles d'or" (BARCELÓ \& LABARTA, 2009, docs. 89, 148 [anys 1576, 1590]).

Cadena. Se citen "una cadena de plata amb dues tisoretes i una altra amb una mà" (GARCIA-OLIVER, 2003: 38 [any 1525]) i una "cadena de oro a la christiana" (BARCELÓ \& LABARTA, 1985: 69 [any 1563]) però no sabem quina era la seua finalitat. Podien servir per a adornar el cap, com a collar o d'altres.

Capell. El 1529 es llega a una dona mudèjar "un capell amb perles" (GARCIAOLIVER, 2003: 129). El 1585 se cita "un capell de perles", potser un ornament per al cap (BARCELÓ, 1984: 107). A més d'un tipus de casquet, podria tractar-se d'una mena de cordó que es col·locava sobre la toca, com les "tiras de cabeza" (Vg. BERNIS, 1979: II, 131).

Cascaveles. Encara que no és gens segur, podrien portar-se penjant d'algun cordó per a adornar el cap o un collar "unos cascaveles de plata e media luna con letras aràbigas" (AHN, Inq. 1lib. 937, f. 227 [any 1590]). També es 


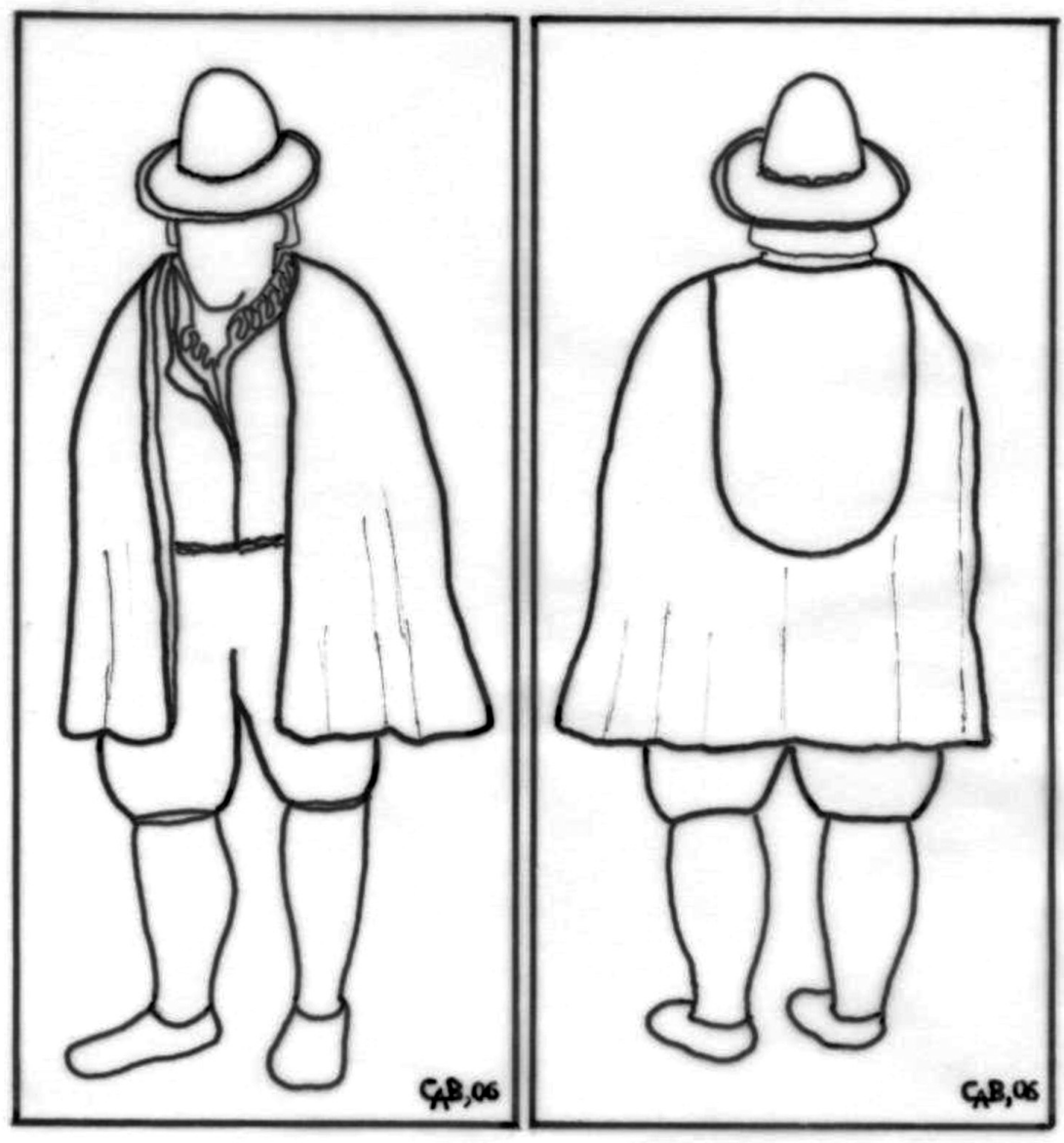

Fig. 8. Home amb capa, de front i d'esquena (inspirat a la sèrie pictòrica Embarque de los Moriscos, 1612-1613, Col-lecció Fundación Bancaja, València). 
pot tractar d'objectes profilàctics, relacionats amb les anomenades "nóminas" i "patenas" (vegeu ací s.v.).

Cinta $<$ maslūt $>$. Era una joia que portaven les dones. "Una cinta d'or adornada amb sis monedes d'or" apareix a una carta de noces d'època mudèjar (BARCELÓ \& LABARTA, 2009, doc. 13 [any 1468]). No hem trobat als diccionaris habituals aquest mot àrab amb cap accepció adient per a aclarir el seu significat en aquest text. A Tunis, però, trobem $<$ salta $>$ com 'cinta o cordonet de seda' (MAHJOUB, 1968: 80) i 'adorn dels cabells compost de cordons de fils d'argent trenats' (SETHOM, 1977: 36), significació que també es recull als textos de Takroûna (MARÇAIS \& GUîGA, 1959, s.v.). Seguint l'ús tunisenc, hem traduït com "cinta" el mot present a l'eixovar de la dona de Fanzara.

Còfia $<$ qufyah $>$. S'adaptava al cap i tenia forma de casquet. S'esmenta en el dot d'una morisca, amb l'especificació que es tracta d'"una còfia de aljófar", és a dir de perletes (APN, Prot. F. Sanchis [any 1604]). Podriem posar-la en relació amb el "capell" abans esmentat i amb els "capillejos" i "capellos" que portaven les dames cristianes d'Espanya (vg. BERNIS, 1979: II, s.v.). En un text del 1591 se cita una "còfia amb perles <qufyah fī jawhar>" (LABARTA, 1983: 82; BARCELÓ \& LABARTA, 2009, doc. 151).

Collar <qlyār $>$ / <hlqa > / <tilālah $>$, pl. <talā'il > Pel que sembla, els collars estaven formats, segons els models, de grans de diferent gruix i material: "un collaret format per deu cases de dos en dos, amb les seues pedres, setze grans d'or i quatre d'argent daurat", "un collar d'or" (GARCIA-Oliver, 2003: 38 [any 1525], 129 [any 1529]); "un collar de or, ab molts grans" (BARCELÓ, 1984: 107 [any 1585]); "un collar de or ab huit dodzenes i deu grans de or morisch, pesant huit dobles" (ARV, Clergat, llig. 752 caixa 1958 [any 1604]); "un collar de oro que tiene ochenta granos redondos de oro" (MAISO \& BlASCO, 1983: 350 [any 1609]). Es troba també "un collar" entre les joies de l'eixovar d'una morisca (APN, Prot. F. Sanchis [any 1604]). N'hi havia també d'altres tipus, compostos de perles i pedres, com ara els que fóren trobats en poder de Ali Eça, mudèjar de Tales (Onda) el 1500: "un collaret de perles, de gruxa los grans com de dacsa, poch més o menys, en sis casetes; ço és, de tres fils cada caseta e cinch grans d'or e dos grans d'argent e quatre pedres de vidre blau; lo qual collaret ha pessat pes de una castellana e un ducat" i també "un altre collaret de perles menudes, com a grans de mill, ab quatre pedres d'ambre e quatre grans d'argent, ço és los dos chichs e los altres dos majors e V grans de coral chiquets; lo qual pessà tot pes de tres castellanes e un florí e .XVII. grans d'or" (BARCELÓ \& LABARTA, 1985: 69-70). Un text àrab del 1518 esmenta un "collar $<$ hlqa $>$ de torneses" i en altre lloc ens dóna el seu equivalent romànic <qlyār> (BARCELÓ, 1984: núm. 157/8 i 14). Alc. recull el mateix terme < hílca, hílaq> sota "armella" i "argolla" i sembla tractar-se d'un tipus de collar no articulat. El Voc. dóna com a equivalent del llatí "torques" ('collar') el mot àrab <tilālah >, pl. <talā'il >, que surt a una carta de noces mudèjar: "tres collars <tlāyl> ornats amb perletes i amb una cornalina" (BARCELÓ \& LABARTA, 2009, doc. 13 [any 1468]). 


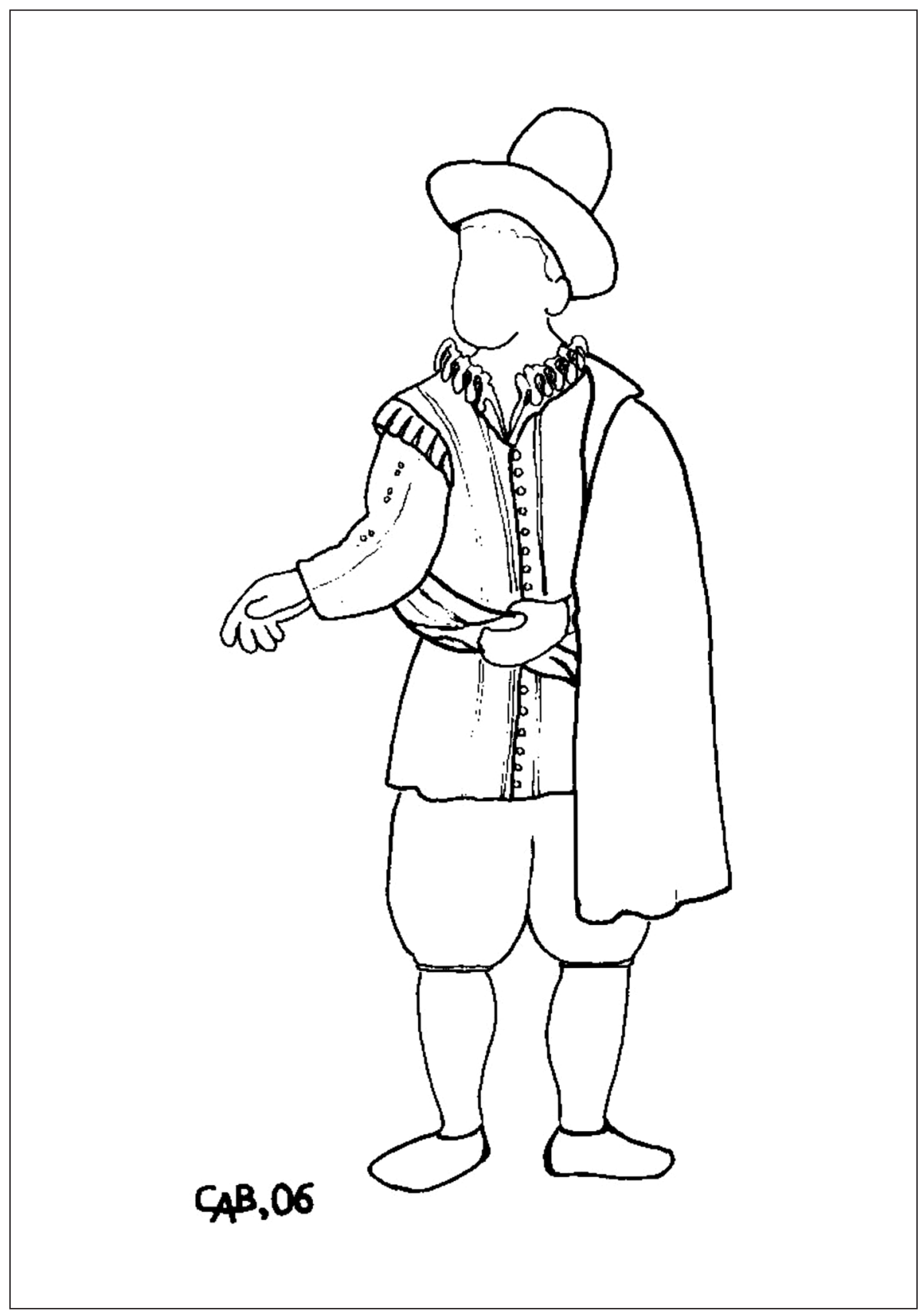

Fig. 9. Home amb capa (inspirat a la sèrie pictòrica Embarque de los Moriscos, 1612-1613, Col-lecció Fundación Bancaja, València). 
Coral. Vg. "collar".

Cornalina. Vg. "collar".

Gisaram (avui jaseran) <jijram>. Peça d'orfebreria feta de malla. Un mudèjar de la moreria de València donà en penyora el 1518 "un gesaram ab cinquanta set perles" (ARV, Batlia, Execucions 332, f. 163v). Un document àrab del 1576 esmenta "un gisaram d'or" i un altre del 1587 explica d'un altre que és de plata (BARCELÓ \& LABARTA, 2009, doc. 189, 140; LABARTA, 1982: 150).

Manilla $<q s$ s $>$. Es tracta de polseres. Segons el tamany, se citen soltes o en grups: "manilles d'or e d'argent" (ARV, Batlia 1147, f. 635 [any 1434]); "una manila de or" (ARV, Batlia, Execucions 332, f. 431v [any 1518]); "manilles de plata" (GARCIA-OLIVER, 2003: 38 [any 1525]); "huit manilles de or" (BARCELO, 1984: 107 [any 1585]); "una manilla de or morisch, pesant sis dobles y mija" (ARV, Clergat, llig. 752 caixa 1958 [any 1604]); "unes manilles de plata" (APN, Prot. F. Sanchis [any 1604]); "cinco pares de manillas de oro hechas a la christiana" (BARCELÓ \& LABARTA, 1985: 69 [any 1563]); "cuatro manillas de oro" (AHN, Inq. llig. 550/11 [any 1602]); "unas manillas de oro" (AHN, Inq. llig. 550/11 [any 1602]; AHN, Inq. 1lib. 939, f. 34 [any 1609]). El mot àrab utilitzat és <qșb $>$, que Alc. dóna com "axorca de oro" i el Voc. traduint el mot llatí "armilla". A un eixovar trobem: "un parell de manilles $<\mathrm{qșb}>\mathrm{d}$ 'or ornades amb nou monedes d'or" (BARCELó \& LABARTA, 2009, doc. 13 [any 1468]).

Nómina $<$ dūmnh $>/<$ dūmna $>$. Sembla que aquest mot es refereix a una mena de medalles, com a plaquetes de metall preciós, també anomenades patenas, que portaven els moriscos com a talismà. Als textos inquisitorials figuren de vegades sota el nom "dóminas" (LABARTA, 1981-1982: 112). El terme àrab $<$ dūmnh $>/<$ dūmna $>$ es repeteix a un document del 1514, tot al-ludint a un objecte de plata pres com a penyora amb altres peces de valor (BARCELÓ, 1984: núm. 151/6, 8, 15, 17 i 19) i el 1525 un text cristià cita "dòmines de plata" (GARCiA-Oliver, 2003: 38). Pensem que s'ha d'interpretar "nòmina", en especial si tenim en compte la pressió del terme llatí "dominus" i la freqüència de les confusions entre fonemes amb i sense nasalització en les llengües romàniques. El 1593 se'n descriu com segueix: "una nómina de oro, con ciertas letras arábigas escritas en ella de la secta de Mahoma" (AHN, Inq. 1lib. 937, f. 542).

Or $<$ dahab $>$. Com a metall preciós és emprat en joies de tot tipus (vg. els apartats d'aquest treball), "un collaret format per deu cases de dos en dos, amb les seues pedres, setze grans d'or i quatre d'argent daurat" i "alfaluls d'or [sic, per alfabubs, és a dir "grans"]" (GARCIA-Oliver, 2003: 38 [any 1525]), "quinze sous per a joies de or" (APN, Prot. F. Sanchis [1604]). Els textos àrabs especifiquen sovint el metall: "deu peces batudes d'or" i de manera genèrica "or" (BARCELó \& LABARTA, 2009, docs. 80, 99, 147 i 148). El fil d'or s'usà per a brodar les vores de vestits i complements. Algunes 
monedes d'aquest metall es duien cosides a la roba: "un vestit de seda, és a dir mitja cota de samit, amb un tarí d'or al coll" (VILA, 1933; BARCELÓ \& LABARTA, 2009, doc. 80 [any 1568]) i d'altres s'utilitzaven com a joies: "un parell de manilles d'or ornades amb nou monedes d'or", "una moneda d'or per al coll ornada amb quatre monedes d'or" (BARCELÓ \& LABARTA, 2009, doc. 13 [any 1468]). Un document cita < barit>, especificant-ne que és “d'or” (BARCELÓ \& LABARTA, 2009, doc. 89 [any 1576]).

Orellal / Orellera. Es tracta de un tipus d'arracada que en castellà rep el nom de 'zarcillo'. El 1372 s'esmenten "unes orelleres de argent” que duia una mudèjar d’Eslida FERRER I MALLOL, 1987: doc. 102). A la Valldigna es documenta "un orellal amb dues alboralles i tres grans d'or" (GARCIA-OLIVER, 2003: 38 [any 1525]).

Patena. Joia relacionada amb la "nómina". Era un tipus de medalla; se'n descriuen dues el 1590: "dos patenas de plata, en la una pintado el sol y en la otra una mano, con letras arávigas" (AHN, Inq. llib. 937, f. 235). S'hi refereix una orde de la Junta de la Capella Reial de Granada (1526), recollida més tard pel Sínode de Guadix (1554) que disposa que els moriscos "no traygan al cuello unas patenas que algunos usan traer con ciertas letras e insignias arábigas con una mano en medio o lunas ni otra cosa semejante y las que tuvieren hechas las deshagan dentro de dos meses y a los plateros mandamos no las hagan" (GALLEGO \& GÁMIR, 1968: 116). La presència de la mà, que coneixem com a "mà de Fàtima", es pot posar en relació amb l'arracada de la fig. 1.

Perla. S'esmenten en un collar d'argent a l'eixovar d'una morisca: "un alhait d'argent amb fils de perles petites penjants" (GARCIA-OLIVER, 2003: 38 [any 1525]). A més de trobar-les decorant còfies i capells o formant part de collars (vg. ací s.v.), veiem que les morisques guardaven perles soltes, tal vegada per a utilitzar-les més tard, com és el cas de Victoria Filomena, la qual posseia "tres onças de perlas" (BARCELó \& LABARTA, 1985: 69 [any 1563]). Vegeu "aljòfar".

Sortija. L'únic testimoni castellà és el de Juan Borbay, de la Vall de Seta, que en 1616 declarà a la Inquisició que "su madre, al tiempo de la expulsión general [...], le dio a éste por despedida, en una bolsa de raso colorada, tres sortijas y un poco de almiscle" (AHN, Inq. 1lig. 549/13). Vegeu més amunt "anillo".

\section{TEIXITS}

Aquest apartat recull els noms àrabs i romànics d'alguns teixits usats a la vestimenta dels moriscos segons la documentació. No hem volgut fer descripció de tècniques textils sinó oferir-ne indicacions i referències textuals que potser serviran en el futur. 


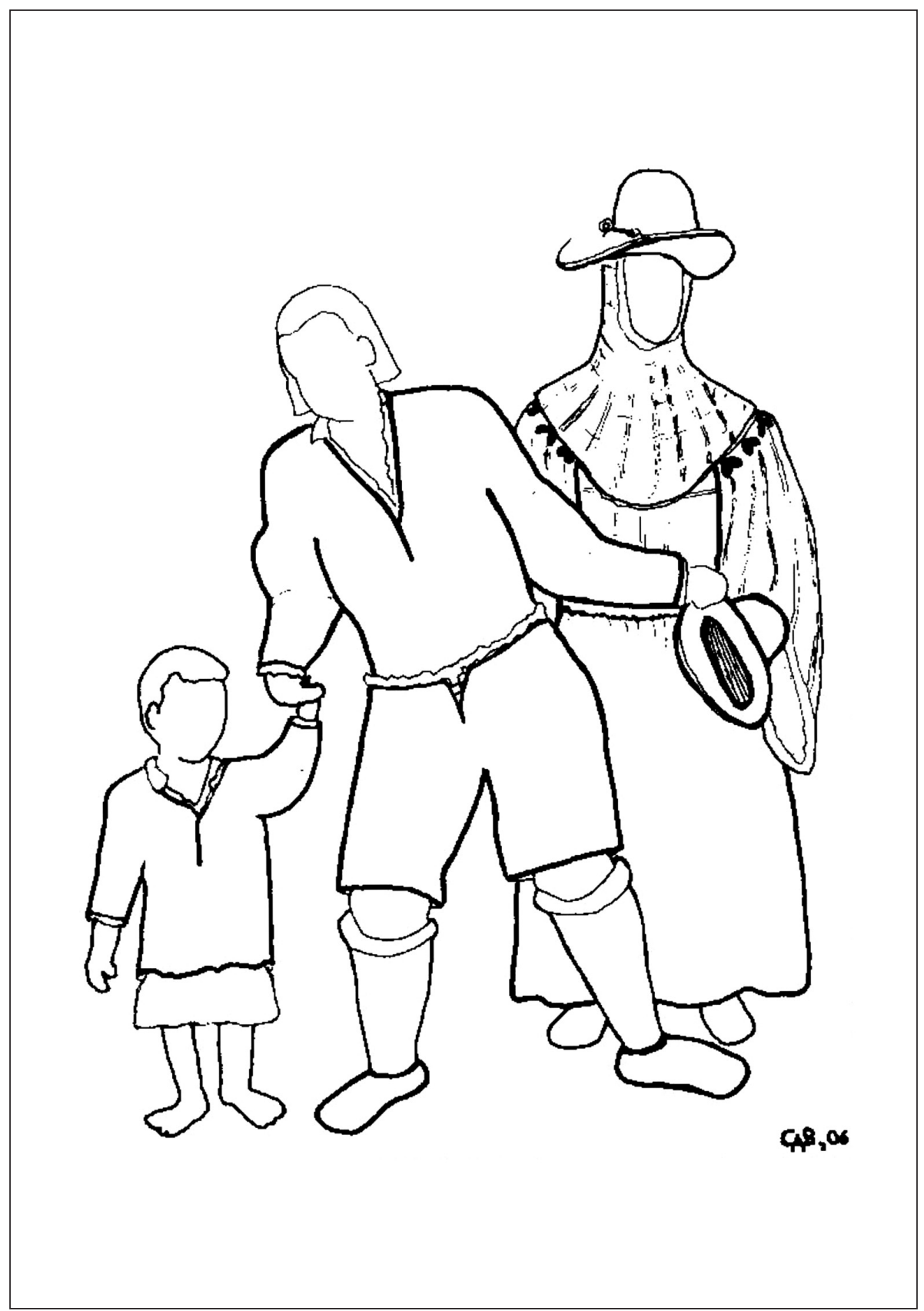

Fig. 10. Grup familiar de camperols moriscos (inspirat a la sèrie pictòrica Embarque de los Moriscos, 1612-1613, Col·lecció Fundación Bancaja, València). 
Baieta. Es troba "vayeta i llens" i "quatre alnes i mija de vayeta negra" com a teixit per a confecció d'alguns caps de vestir, a més d"'una saboyana de vayeta" (ARV, Clergat, llig. 749 caixa 1949-50 [any 1583]).

Bis $<$ xarb al-harīr $>$. Es refereix a un teixit molt fi i delicat, en aquest cas fet de seda, encara que podia ser d'altres materials (DOZY, I: 740a). S'esmenten "dues alvacaïes de bis de seda, les vores daurades" (BARCELÓ \& LABARTA, 2009, doc. 57 [circa any 1525]).

Camelot / Chamellot / Chamelote <jmālyt $>$. Aquest teixit estava fet de llana o de seda; se citen "unes sayes de chamellot usades de carmesí ab barret de bellut” (ARV, Batlia 329, f. 631 [any 1513]) i la morisca Victoria Filomena tenia "una saya de chamelote carmessí guarnecido con terciopelo negro" i una "saya de chamelote amarillo, guarnecido con terciopelo carmessí o de grana" (BARCELÓ \& LABARTA, 1985: 69 [any 1563]). En un text àrab "mitja cota de jamelot" (BARCELÓ \& LABARTA, 2009, doc. 148 [any 1590]).

Cerro $<$ jr $>$. Es tracta de floca de cotó, llana, cànem o lli per a ser filada. Una de les prestacions personals de les musulmanes valencianes era filar cerro de lli o cànem per al senyor (GUAL, 1949); també se'n cita als albarans àrabs de lliurament del filat per les aljames de la Marina al segle XIV (BARCELÓ, 1984: núms. 26-28 [any 1368]). El mot aràbic es documentava ja al Voc. com equivalent del llatí linum.

Drap. Vegeu "tela".

Espiguilla. Pensem que seria una mena de treneta o cinta, tot i que no l'hem trobada amb aquesta accepció a la bibliografia sobre teixits. Auns comptes es diu que "costaren unes maçanetes y espiguilla 14 sous 5 diners" (ARV, Clergat, llig. 749 caixa 1949-50 [any 1583]). Podria posar-se en relació amb la trena d'or citada amb "unas mangas de terciopelo negro guarnecidas con una trença de oro" (BARCELÓ \& LABARTA, 1985: 69 [any 1563]).

Estamenya $<$ ixtaminya $>$ / <ixtamiina $>$. Teixit de llana al qual urdim i trama són d'estam, de construcció solta, sense dibuix i igual pels dos costats. D'aquesta tela $<$ ixtaminya $>$ s'havia confeccionat la saya d'una morisca (LABARTA, 1983: 82; BARCELÓ \& LABARTA, 2009, doc. 151 [any 1591]); es comprà "set pams de estamenya <ixtamiina>" (BARCELÓ \& LABARTA, 2009, doc. 120 [segle XVI]).

Estopa $<$ ixtub $>/<$ ixtūb $>$. Apareix entre els productes que filaven les aljames de la Marina per al senyor (BARCELÓ, 1984: núms. 26/3 i 28/3 [any 1368]). Vegeu "cerro" i "llenç".

Llana $<$ șūf $>$. Apareix sovint entre els béns de l'eixovar de la núvia; normalment en quantitat d'un quintar. A l'època morisca potser es tractava d'un lliurament simbòlic (LABARTA, 1983; BARCELÓ \& LABARTA, 2009, docs. 57, 99 [circa 1525, 1570-1580]).

Llenç / Lienço. En textos àrabs trobem $<$ xuqah $>,<$ al-xūqah $>,<$ al-xuqah $>,<$ axuqaq $>$, <al-xuqāq $>$. Segons Alc. la paraula $<$ xuca, xúqca, xóqca, xoqca $>$ 
designava "tela", "lienço, paño de lino", "naval lienço", "tela de cedaço". En documents del segle XIV pareix que es tracta del llenç que s'obté del cànem que, segons el seu procés d'elaboració, donava lloc a la estopa, estopó, clavell i cerro (BARCELÓ, 1984: núms. 20/2, 24/1, 26/2, 27/ 1 i 31/1 [any 1368]). Un text cita una almeixia de "llenç, brodada en seda rosa i aranjat" i altres dues, també de llenç, una amb brodats "el faldar i les bocamànegues", i una altra "amb seda roja a les bocamànegues i el faldar" i en un cas s'esmenta "llenç" o "tela per a una alcandora" (BARCELÓ \& LABARTA, 1985: 65/66, 1. 8, 11, 9-10; LABARTA, 1994: 62; BARCELÓ \& LABARTA, 2009, docs. 74, 132 [anys 1559 i 1581-1583]). En una relació de despeses fetes per la custòdia d'unes xiquetes se cita la compra de "vayeta i llens" i de "llens y veta" (ARV, Clergat, llig. 749 caixa 1949-1950 [any 1583]). Segons un testimoni, els moriscos oferien de present als alfaquins "gallinas y lienços" (AHN, Inq. llig. 551/ 43 [any 1605]), sense que es puga saber si es tractava de trossos de teixit destinats a fer vestits o bé a d'altres usos, com ara "un lienço para hazer colchones moriscos de colores" i "un pedaço de lienço delgado que será de dos varas" citats a un inventari (AHN, Inq. llig. 554/18 [any 1602]).

Lli $<$ ktān $>/<$ kitan $>/<$ ktny $>$. Matèria tèxtil d'origen vegetal de la qual es feien teixits de luxe. Al segle XIV en els comptes del senyoriu de molts pobles de la Marina les dones mudèjars apareixen teixint lli per a la casa del senyor (BARCELÓ, 1984: núms. 15/3 i 26/2 [any 1368]). Formava part dels eixovars de les morisques, normalment mesurat en quintars (VILA, 1933; LABARTA, 1983; BARCELÓ \& LABARTA, 2009, docs. 57, 80, 99 i 147).

Maçanetes. Seria un tipus d'ornament semblant al que en diem pometes o borles. Se citen a un inventari de despeses "unes maçanetes y espiguilla" (ARV, Clergat, llig. 749 caixa 1949-1950 [any 1583]).

Passaman $<$ baxaman $>$. En un document dels anys 1581-1583 s'esmenta dues vegades aquesta cinta destinada a ornar la vora de la roba (LABARTA, 1994: f. 4r, 6v; BARCELÓ \& LABARTA, 2009, doc. 132).

Raso $<$ rsh $>$. Tela de seda brillant de la qual estava fet un manto (LABARTA, 1982; BARCELÓ \& LABARTA, 2009, doc. 140 [any 1587]. Vg. BERNIS, 1979: II, s.v. i DozY, I, 495b s.v. <rāsa>). A un inventari de béns d'una dona s'esmenta "un cuerpo de rasso carmessí con sus mangas" (BARCELÓ \& LABARTA, 1985: 69 [any 1563]). En 1616 se cita "una bolsa de raso colorada" (AHN, Inq. llig. 549/13).

Raxa. Era una tela de bona qualitat (Alcover \& MolL, s.v. raixa). A les despeses fetes per dues xiquetes s'inclou "una alna de raxa negra [...] per a dos gipons” (ARV, Clergat, llig. 749 caixa 1949-1950 [any 1583]).

Rissa $<$ risā $>$. Podria tractar-se d'un teixit en què un segon ordit forma anelles sobre el fons, com en les tovalloles. COROMINES (DECat, VII: $328 \mathrm{~b}$ ) recull algunes mostres del terme rissa (i el seu masculí ris) a documents castellans i catalans del segle XVI. A un inventari àrab trobem: "un torcamà 
amb rissa" (BARCELÓ \& LABARTA, 1985: 65/66, 1. 16; BARCELÓ \& LABARTA, 2009, doc. 74 [any 1559]).

Samit $<x m d>$. Tela rica de seda que s'esmenta com a component d'una cota "blau cel de tela amb samit grana" (LABARTA, 1982: fol. 3 r; BARCELÓ \& LABARTA, 2009, doc. 140 [any 1587]), d'una mitja cota "amb un tarí d'or al coll”, a més d'un "jaquet” i d'“un capell” (VILA, 1933; BARCELÓ \& LABARTA, 2009, docs. 80, 148 [anys 1568 i 1590]).

Sayal $<$ șyl $>$. El sargil o teixit rústic de llana, amb el qual es feien a època medieval peces de vestir, apareix al segle XVI en castellà transcrit a l'àrab: "tres sayals" (BARCELó \& LABARTA, 2009, doc. 120).

Seda $<$ ḥarir $>$ / < harīir $>$. Apareix sovint a les cartes dotals com a component de l'eixovar morisc i se cita també com a teixit de què estan fetes diverses peces de vestir, com ara almeixies, toques, vetes i gonelles, a més a més d'esmentarse en accessoris d'una casa ("cortinas") o en teixits ("telas") (LABARTA, 1982, 1983 y 1994: 66/ 70; VILA, 1933; BARCELÓ, 1984: núm. 151/7 [any 1514]; BARCELÓ \& LABARTA, 2009, docs. 73, 80, 99, 132, 140, 147, 151). Vg. Alc. s.v.

Seda alducar $<\mathrm{qz}>/<\mathrm{kiza}>/<$ al-qazi $>$. Rebé aquest nom la seda de menor qualitat provinent de l'exterior del capell o de capells defectuosos o tacats i per extensió, la tela teixida amb ella (DOZY, s.v. <qazz>; SERRANO-NIZA, 2005: 42; SANTOS ISERN, 1981: 1983 i ss.). Apareix en un text de la zona de Gandia, productora de primera magnitud, pesada en unces (LABARTA, 1982: 154; BARCELÓ \& LABARTA, 2009, doc. 140 [any 1587]).

Setí <sata_rus $>$. Segons les ordinacions del gremi de sabaters de València s'utilitzava el setí per a recobrir un tipus de sabates (PILES, 1959). Encara avui se'n fa ús en el calcer de les dones que vesteixen la indumentària fallera. Quant a $<$ rus $>$, podria referir-se a l'adjectiu de color "ros" o bé al-ludir a un tipus de setí "rasat" (SESMA \& LíBANO, 1982: 151). Se cita diverses vegades en un document del 1573: "sabates [...] de setí ras" (BARCELÓ \& LABARTA, 1985: 67/68, 1. 3, 6, 8, 9, 10, 11; BARCELÓ \& LABARTA, 2009, doc. 85).

Tafetà $<$ tifataf $>$. Es tracta del teixit de seda llis, amb ordim i trama del mateix gruix (que, com és sabut, és la forma més senzilla de teixir) però molt atapeï. El trobem tot sol o en combinació amb vellut i teles treballades (LABARTA, 1994: 69 / 65; BARCELÓ \& LABARTA, 2009, doc. 132 [anys 1581-1583]). Entre els béns de Victoria Filomena hi havia "una ropa grande de tafetán girasol que la llaman loba, con alas, guarneçida de terçiopelo de grana" (BARCELÓ \& LABARTA, 1985: 69 [any 1563]).

Tela $<$ mlf $>$ / $<$ malfi $>$ / $<$ malf $>$. Pareix que es va utilitzar en algunes èpoques en el sentit de teixit de llana grossa i de pèl curt, però entre els béns de les morisques s'usà més sovint com a genèric $i$ amb aquest últim sentit trobem: "teles per a llurs vestits <malaf li-libāsi-himā >", "tres alnes de tela" i també "cinc pams de tela" (LABARTA, 1994: 62 ; BARCELÓ \& LABARTA, 2009, docs. 73, 132, 154 [anys 1557, 1581-1583, 1593], doc. 120 [segle XVI]). Eren fetes amb aquest teixit "una cota blau cel de tela amb samit grana" i "una 
gonella” (LABARTA, 1982: 153, f. 3r; LABARTA, 1983: 82; BARCELÓ \& LABARTA, 2009, docs. 140, 151 [anys 1587, 1591]). La tela més senzilla, de color burell o terròs, sense tenyir, rebia en castellà el nom de "pardillo"; terme que es documenta el 1587: "un parell de saraüells pardillos sense trinxa" (LABARTA, 1982: 155, f. 9v i 10 r; BARCELÓ \& LABARTA, 2009, doc. 140).

Trepa $<$ itribā $>$. Només hem trobat una citació d'aquest mot: "una faldeta de grana, amb trepa de seda negra" (BARCELÓ \& LABARTA, 1985: 66; BARCELÓ \& LABARTA, 2009, doc. 74 [any 1559?]). El 1985 pensavem que l'àrab era reflex del romanç tripa, teixit fet de llana o espart, similar al vellut. No obstant això, ara creiem que s'ha de llegir 'trepa' i que es tracta de l'adorn o guarnició que es posava a la vora dels vestits. Aquest terme va designar també l'obertura practicada a una peça de tela sota la qual es veia tela d'un altra classe o color (AlCOVER \& Moll, s.v.). No creiem, però, que el text àrab reflectisca aquesta accepció, ja que llavors hauria estat en plural.

Vellut $<$ biylūt $>$. A més a més de les nombroses referències que hi ha en la descripció de robes, s'esmenta com a despesa de material abans de cosir diversos tipus de vestits, com ara: "una alna de vellut carmesí", "mija alna de vellut verd" (ARV, Clergat, llig. 749 caixa 1949-1950 [any 1583]). Trobem "un jaquet de vellut" a l'inventari dels béns de l'eixovar d'una morisca d'Albalat de Tarongers, ja difunta (BARCELÓ \& LABARTA, 2009, doc. 154 [any 1593]) i "una marlota de vellut guarnida ab randes de or" a l'eixovar d'una de la Vall d'Uixò (APN, Prot. F. Sanchis [any 1604]).

Veta. La veta és un teixit en forma de cinta. S'usa per a vorejar, embenar o lligar i se cita "llens y veta" (ARV, Clergat, llig. 749 caixa 1949-1950 [any 1583]).

Vora $<$ haxyā $>$, $<$ hawixi $>$. Potser es tracta de la vora brodada que guarneix els vestits, confeccionada de vegades en seda. Alc. diu "orilla de vestidura, orilla bordada y orillo de paño <háxia havíxi>". Apareix dues vegades en un document del 1559: "una almeixia de seda amb vores morat $i$ aranjat" i "un troç de vora de seda groc, verd i roig" (BARCELÓ \& LABARTA, 1985: 66/67, 1.7 i 21; BARCELÓ \& LABARTA, 2009, doc. 74; creiem que s'ha de corregir on vàrem llegir i traduir: <'axyā> "recam").

\section{BIBLIOGRAFIA I ABREVIATURES}

$\mathrm{ADV}=$ Arxiu Diocesà de València.

AHN = Arxiu Històric Nacional (Madrid). Secció Inquisició (=Inq.)

AlbARRACín, Joaquina (1964), Vestido y adorno de la mujer musulmana de Ŷebala (Marruecos), Madrid, CSIC.

AlbarRAcín, Joaquina (1997), «Nueve cartas moriscas de dote y arras de Vera (Almería) (1548-1551)», Actas del Congreso la Frontera Oriental nazarí como sujeto histórico (s. XIII-XVI). Almería, Diputación Provincial, pp. 517-529. 
Alc. = Pedro de AlCALÁ, De lingua arabica libri duo (ed. P. Lagarde), Göttingen, 1883 [reprint Osnabrück, 1971].

Alcover, Antoni Maria \& Moll, Francesc de Borja (1926-1962), Diccionari catalàvalencià-balear [reprint: Palma de Mallorca, Editorial Moll, 1980], 10 vols.

AMS = Arxiu Municipal de Sogorb.

$\mathrm{AMV}=$ Arxiu Municipal de València.

APN $=$ Arxiu de Protocols de Nules.

ARCAS CAMPOY, María (1991), «Inventario de bienes de una morisca granadina emigrada a Lorca (Murcia)», Al-Masaq, 4, pp. 35-49.

ARV = Arxiu del Regne de València.

BARCELÓ, Carmen (1980), «La morería de Valencia en el reinado de Juan II», Saitabi, 30, pp. 47-71.

BARCeló, Carmen (1984), Minorías islámicas en el país valenciano. Historia y dialecto. Madrid-Valencia, IHAC-Universitat de València.

BARCEló, Carmen \& LABARTA, Ana (1985), «Indumentaria morisca valenciana», Sharq al-Andalus, pp. 49-73.

Barceló, Carmen \& Labarta, Ana (2009), Archivos moriscos, València, PUV.

BARRERA MATURANA, José Ignacio (2007), «Representación de una mujer morisca en un graffiti del Albayzín (Granada)», Anaquel de Estudios Árabes, 18, pp. 65-91.

BERNIS, Carmen (1956), Indumentaria medieval española, Madrid, CSIC.

BERNIS, Carmen (1959), «Modas moriscas en la sociedad cristiana española del siglo XV y principios del siglo XVI», Boletín de la Real Academia de la Historia, 144, pp. 199-228.

BERNIS, Carmen (1962), Indumentaria española en tiempos de Carlos V, Madrid, CSIC.

BERNIS, Carmen (1978), Trajes y modas en la España de los Reyes católicos, I. Las mujeres, Madrid, CSIC.

BERNIS, Carmen (1979), Trajes y modas en la España de los Reyes católicos, II. Los hombres, Madrid, CSIC.

BORONAT, Pascual (1901), Los moriscos españoles y su expulsión, Valencia, 2 vols.

COROMINES, Joan (1980-1991), DECat = Diccionari etimològic i complementari de la llengua catalana, Barcelona, Curial, 9 vols.

COVARrubiAs, Sebastián (1611), Tesoro de la lengua castellana o española, Martín de RiQuer (ed.), Barcelona, 1943 [reprint Barcelona, 1987].

Dozy, Reinhard P.A. (1845), Dictionnaire détaillé des noms des vêtements chez les arabes, Amsterdam [reprint Beirut s.a].

Dozy, Reinhard P.A. (1927 [2 ${ }^{\mathrm{a}}$ ed.]), Supplément aux dictionnaires arabes, LeidenParis [reprint, 1967]. 
Expvlsión (1997), La Expvlsión de los Moriscos del Reino de Valencia (Catàleg de l'exposició de la col·lecció de pintures de la sèrie Embarque de los Moriscos (1612-1613), port de Vinaròs i Grao de València, de Pere Joan Oromig, port de Dénia, de Vicent Mestre i port d'Alacant, de Pere Joan Oromig i Francesc Peralta, junt a d'altres de les rebel·lions i arribada al port d'Orà), València, Fundación Bancaja.

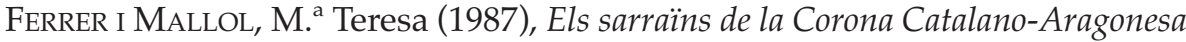
en el segle XIV: segregació i discriminació, Barcelona, CSIC.

GALLEGO, Ángel \& GÁMIR, Antonio (1968), Los moriscos del reino de Granada según el sinodo de Guadix de 1554, Universidad de Granada.

García Mercadal, José (ed.) (1959), Viajes de extranjeros por España y Portugal desde los tiempos más remotos hasta fines del siglo XVI, Madrid, Aguilar S.A., 2 vols.

GARCIA-Oliver, Ferran (2003), La Vall de les sis mesquites. El treball i la vida a la Valldigna medieval, Universitat de València.

Gual Camarena, Miguel (1949), «Mudéjares valencianos, aportaciones para su estudio», Saitabi, 7, pp. 165-199.

Gual Camarena, Miguel (1952-53), «Concordia entre los gremios de zapateros y chapineros de Valencia (1486)», Saitabi 9, pp. 133-144.

LABARTA, Ana (1981-1982), «Notas sobre algunos traductores de árabe en la Inquisición valenciana (1565-1609)», Revista del Instituto Egipcio de Estudios Islámicos, 21, pp. 101-133.

LABARTA, Ana (1982), «Cuentas del tendero morisco Gerónimo Hoix (Gandía, 1587)», Al-Qanțara, 3, pp. 135-171.

LABARTA, Ana (1983), «Contratos matrimoniales entre moriscos valencianos», $A l$ Qanțara, 4, pp. 57-87.

LABARTA, Ana (1994), «Contabilidad del morisco valenciano Josep Malux en los años 1581-1583», Saitabi, 44, pp. 57-72.

LABARTA, Ana, vegeu BARCELÓ.

LASMARÍAS PONZ, Israel (2007), «Vestir al morisco, vestir a la morisca: el traje de los moriscos en Aragón en la Edad Moderna», X Simposio Internacional de Mudejarismo. Actas, Teruel, pp. 629-641.

MaHJOUB, Neziha (1968), «Le costume hanéfite des hommes de religion et de justice à Tunis», Cahiers des Arts et Traditions Populaires de Tunisie, 2, pp. 79-92.

MAIso, Jesús \& BlAsco, Rosa (1983), «Dos señoríos alicantinos con vasallos moriscos a través de los registros notariales», Les Morisques et leur temps, Paris, CNRS, pp. 335-354.

MARÇAIS, William \& GUîGA, Abderrahmân (1925-1961), Textes arabes de Takroûna, Paris, 2 vols.

MARíN, Manuela (1997), «L'habillement des femmes dans al-Andalus», Recherches Regionales (Nice), 147, pp. 31-41. 
MARÍN, Manuela (1998), «Mujeres veladas: religión y sociedad en al-Andalus», Arenal: Revista de Historia de las Mujeres, 4/1, pp. 23-38.

MARín, Manuela (ed.) (2001), Tejer y vestir: de la Antigüedad al Islam, Madrid, CSIC.

Martínez MelÉndez, M. a del Carmen (1989), Los nombres de tejidos en castellano medieval, Granada, Universidad de Granada.

MARTínez Ruiz, Juan (1967), «La indumentaria de los moriscos según Pérez de Hita y los documentos de la Alhambra», Cuadernos de la Alhambra, 3, pp. 55-124.

Martínez Ruiz, Juan (1967b), «Almohadas y calzados moriscos», Revista de Dialectología y Tradiciones Populares, 13, pp. 289-313.

MARTínez RuIZ, Juan (1972), Inventarios de bienes moriscos del reino de Granada (siglo XVI). Lingüística y civilización, Madrid, CSIC.

Martínez Albarracín, Carmen A. (1995), «Juan Martínez Ruiz y la carta de dote y arras de una morisca», VI Simposio Internacional de Mudejarismo. Actas, Teruel, pp. 833-844.

MARTínez AlbarRacín, Carmen A. (1999), «Léxico de algunas ropas y joyas de una carta de dote y arras de una morisca granadina del siglo XVI (24-I-1563)», VII Simposio Internacional de Mudejarismo. Actas, Teruel, pp. 679-689.

MEYerson, Mark D. (1986), «The War against Islam and the Muslims at home: The Mudejar Predicament in the Kingdom of Valencia during the reign of Fernando "El Católico"», Sharq al-Andalus. Estudios Árabes, 3, pp. 103-113.

MongA, Luigi (ed.) (1985), Un mercante di Milano in Europa. Diario di viaggio del primo Cinquecento, Milano, Jaca Book.

MüNZER, Jerónimo (1494-1495), Viaje por España y Portugal, Madrid, 1991, Ed. Polifemo.

NAVAGERO, Andrés (1524-1526), Viaje por España, traduït i anotat per Antonio Maria Fabie, Madrid, 1983, Ed. Turner.

OsOrio PÉreZ, M. José (1993), «Aproximación al status socio-económico de la mujer morisca a través de los protocolos granadinos: fuentes para su estudio», IV Simposio Internacional de Mudejarismo. Actas, Teruel, pp. 667-675.

PILES Ros, Leopoldo (1959), Estudio sobre el gremio de zapateros, Valencia.

RAmírez MARTínez, J.M. (ed.) (1981), Las ordenanzas de la ciudad de Logroño. Año 1607, Logroño.

ROCA TRAVER, Francisco (1952), «Un siglo de vida mudéjar en la Valencia medieval (1238-1338)», Estudios sobre la Edad Media en la Corona de Aragón, 5, pp. 115-208.

SANTOS ISERN, Vicente M. (1981), Cara y cruz de la sedería valenciana (siglos XVIIIXIX), Valencia.

SERRANO-NiZA, Dolores (2005), Glosario árabe español de indumentaria según el Kitāb al-mujașșaș de Ibn Sīdah, Madrid, CSIC. 
SERRANO-NIZA, Dolores (2005a), «El léxico castellano medieval se viste con palabras árabes. Algunos arabismos de indumentaria», Sacrum Arabo-Semiticum. Homenaje al profesor Federico Corriente en su 65 aniversario, Zaragoza, IEIOP.

Serrano-NizA, Dolores; GonzÁlez Marrero, M. Cristo \& Romero Morales, Yasmina (2008), Granada, un reino de seda: su legado en una nueva ruta de escenarios atlánticos, Granada.

SESMA, J. Antonio \& LíBANO, Ángeles (1982), Léxico del comercio medieval en Aragón (siglo XV), Zaragoza.

SETHOM, Samira (1977), «Etude de quatre contrats de mariage Sfaxiens du XIXe siecle», Cahiers des Arts et Traditions Populaires de Tunisie, 6, pp. 19-36.

VILA, Salvador (1933), «Un contrato de matrimonio entre musulmanes del siglo XVI», Anales de Historia del Derecho Español, 10, pp. 186-196.

Voc. $=$ Vocabulista in arabico, C. Schiaparelli (ed.), Firenze, 1871.

WeIDITZ, Christoph (1529), Das Trachtenbuch des Christoph Weiditz von seinen Reisen nach Spanien (1529) und den Niederlanden (1531/1532), Ed. Theodor Hampe, Berlin-Leipzig, 1927.

\section{RESUMEN}

Reelaboración y reactualización de un trabajo ya publicado en esta revista (Sharq Al-Andalus, 2, 1985, pp. 49-73) en torno a la indumentaria de los moriscos valencianos. Aportación de numerosos datos nuevos a partir de documentos árabes y representaciones gráficas aparecidos en los últimos años. Extenso listado léxico de nombres de prendas, con indicación de su étimo árabe, identificación, descripción y paralelos documentales.

Palabras clave: moriscos, Valencia, indumentaria, léxico.

\section{ABSTRACT}

Re-edition and updating of a previous work (published in Sharq Al-Andalus, 2, 1985, pp. 49-73) about the dress of Valencian moriscos. It includes several new data from Arabic documents and graphic depictions appeared in the last few years. It also includes an extensive dictionary of the garment names, with the Arabic etymological term, identification, description and documentary parallels.

Key words: Moriscos, Valencia, dress, dictionary. 